\title{
Nervus belli, pecunia infinita - mletački plan o zauzeću Zadra u zapisniku inkvizicijskoga sudskog postupka iz 1346. godine ${ }^{* *}$
}

U arhivskom fondu Obitelj Fanfogna-Garagnin Državnoga arhiva u Splitu među spisima zadarske plemićke obitelji Fanfogna nalazi se zapisnik o inkvizicijskom sudskom postupku iz rujna 1346., sačuvan u prijepisu iz 18. stoljeća. Zapisnik svjedoči o provedenoj istrazi zadarskoga kaznenog suda protiv firentinskoga plemića Uguiccionea Dellosti, optuženog za tajni dogovor s Mlečanima o zauzeću Zadra tijekom posljednje faze mletačko-zadarskoga rata. S obzirom na to da je zapisnik prepisan iz izgubljenoga registra kaznenih predmeta (Quaternus criminalium) za srednjovjekovni Zadar, taj je dokument i jedino pisano svjedočanstvo o zadarskom kaznenopravnom sustavu i sudskoj praksi u prvoj polovini 14. stoljeća. Prijepis ovoga zapisnika potvrđuje i da se spomenuti registar još uvijek nalazio u Zadru u 18. stoljeću. Osim vanjskih karakteristika prijepisa, u članku se istražuje i sadržaj zapisnika radi utvrđivanja istinitosti zapisanih podataka i njihove korelacije sa sličnim podacima iz ostalih izvora istoga razdoblja (vremenska i prostorna rekonstrukcija). Sadržajnom analizom zapisnika utvrđeni su pravni i vojno-politički aspekt teksta koji određuju vrijednost ovoga dokumenta. Osim što zapisnik potvrđuje postojeće spoznaje o kaznenopravnoj povijesti Zadra u 14. stoljeću, donosi i nova saznanja koja upotpunjuju postojeću sliku o događanjima tijekom mletačke opsade grada, posebno o ulozi mletačkih zapovjednika i stranih plaćenika u planiranju i izvođenju ratnih djelovanja.

Ključne riječi: Zadar, 14. stoljeće, opsada, Mlečani, toskanski plaćenici, kazneni zapisnici, inkvizicijski postupak

Sandra Begonja, Hrvatski institut za povijest, Opatička 10, 10000 Zagreb, Republika Hrvatska, E-mail adresa:phelgor@yahoo.co.uk

** Ovaj je rad financirala Hrvatska zaklada za znanost projektom Topografija vlasti: istočnojadranski gradovi u srednjovjekovnim prostorima vlasti (TOPOS), broj IP-2019-04-2055. 


\section{Uvod}

U arhivskom fondu Obitelj Fanfogna-Garagnin (1301. - 1901.) Državnoga arhiva u Splitu nalazi se zapisnik koji svjedoči o inkvizicijskom sudskom postupku provedenom u vrijeme mletačke opsade Zadra (1345. - 1346.), sačuvan u prijepisu iz 18. stoljeća. ${ }^{1}$ Dokument je pronađen pri istraživanju arhivskih fondova vezanih za gradsko plemstvo srednjovjekovnoga Zadra u Državnom arhivu u Splitu. ${ }^{2}$

Riječ je o neistraženom fondu čija je sačuvana dokumentacija nastala u sklopu obiteljske kancelarije i arhiva Fanfogna u Zadru (18. stoljeće), ${ }^{3}$ a o kojoj nema previše saznanja u postojećoj literaturi. Prema dostupnim podacima, dijelovi toga obiteljskog arhiva nalaze se danas u arhivima Zadra, Zagreba i Splita. ${ }^{4}$ Manji

1 Hrvatska (dalje: HR) - Državni arhiv u Splitu, Split (dalje: DAST) - fond 156 - Obitelj Fanfogna-Garagnin (1301. - 1901.), K. 2 (klasa) (dalje: Obitelj Fanfogna-Garagnin). Fond trenutačno nije arhivistički sređen i u postupku je obrade. S obzirom na stanje fonda nije bilo moguće navesti točne oznake pripadajuće tehničke, arhivske ili popisne jedinice ni točnu paginaciju dokumenta u ovom radu (u dokumentu ne postoje obilježja stare paginacije). Ovom prilikom zahvaljujem djelatnicima Državnoga arhiva u Splitu na stručnoj pomoći koju su mi pružili pri istraživanju fonda.

2 Osobni uvid u sadržaj ovoga obiteljskog fonda imala sam prilike dobiti tijekom znanstveno-istraživačkoga proučavanja zadarskih plemićkih obitelji u Državnom arhivu u Splitu 2011. godine. Istraživanje je provedeno u sklopu projekta Grad hrvatskog srednjovjekovlja: društvene strukture, topografija, urbani život (voditelj: dr. sc. Irena Benyovsky Latin, Hrvatski institut za povijest).

3 O obiteljskoj knjižnici i arhivu Fanfogna u Zadru vidi: „Arhivsko gradivo. Obitelj Fanfogna-Garagnin” (HDA), pristup ostvaren 7. 9. 2020., http://arhinet.arhiv.hr/details.aspx?ItemId=1_4630; „Arhivsko gradivo. Obitelj Fanfogna" (DAZD) pristup ostvaren 7. 9. 2020., http://arhinet.arhiv.hr/details. aspx?ItemId=1_15463; Hrvoje Morović, „O trogirskoj knjižnici Garanjin-Fanfonja”, Vjesnik bibliotekara Hrvatske 10 (1964), br. 3-4: 98.

4 Nekoć cjeloviti obiteljski fond Fanfogna danas je ostao sačuvan u različitim arhivskim fondovima na nekoliko lokacija: u Hrvatskom državnom arhivu (HR-HDA-713, Obitelj Fanfogna-Garagnin, 1175. - 1807.), Državnom arhivu u Zadru (HR-DAZD-354, Obitelj Fanfogna, 1355. - 1673.) i Državnom arhivu u Splitu (HR-DAST-156, Obitelj Fanfogna-Garagnin). Osim glavnoga fonda Fanfogna, u zadarskom arhivu postoje i obiteljski spisi Fanfogna u fondu obitelji Corponese te zapisi o obitelji razbacani unutar različitih fondova. Vidi: HR-DAZD-349, u: „Arhivsko gradivo. Obitelj Corponese” (DAZD), pristup ostvaren 7. 9. 2020., http://arhinet.arhiv.hr/details.aspx?ItemId=1_15458. Vidi i: HRDAZD-356, u: DAZD, „Vodič Državnog arhiva u Zadru. Obitelj Katić”, pristup ostvaren 7. 9. 2020., https://vodic.dazd.hr/dazd-0356/ i HR-DAZD-377, Miscellanea - svež. 15, Poz. 20. Priznanje plemićkih naslova obitelji, u: DAZD, „Vodič Državnog arhiva u Zadru. Obitelj Fanfogna”, pristup ostvaren 7. 9. 2020., https://vodic.dazd.hr/dazd-0354/. Pojedini obiteljski spisi postoje i u Znanstvenoj knjižnici u Zadru (HR-ZKZD-100, Obitelj Fanfogna, u: DAZD, „Vodič Državnog arhiva u Zadru. Obitelj Fanfogna") te vjerojatno i u knjižnici Garagnin-Fanfogna u sklopu Muzeja grada Trogira. Vidi: Jakov Stipišić, „Regesta pergamena iz zbirke obitelji Fanfogna Garagnin u Muzeju grada Trogira (Dio prvi - Pergamene XIII., XIV. i XV. stoljeća)", Zbornik Odsjeka za povijesne znanosti Zavoda za povijesne i društvene znanosti HAZU 20 (2002): 289-321. O navedenom vidi: „Arhivsko gradivo. Obitelj Fanfogna-Garagnin” (HDA); „Arhivsko gradivo. Obitelj Fanfogna” (DAZD); Dubravka Kolić, Robert Leljak, HR-DAZD-354 Obitelj Fanfogna (1355. - 1673.). Sumarni inventar (Zadar: Državni arhiv u Zadru, 2009), 3-8, pristup ostvaren 7. 9. 2020., https://www.dazd.hr/attachment/preview/5c657cc7df007/ dazd-354-Fanfogna.pdf; Dubravka Kolić, HR-DAZD-349 Corponese (1413. - 1844.). Analitički inven- 
dio obiteljskoga arhiva Fanfogna postaje sastavnim dijelom jedinstvene zbirke trogirske knjižnice i arhiva obitelji Garagnin-Fanfogna, a veći dio ostaje i dalje u posjedu obitelji u Zadru nakon 1840 . godine. ${ }^{5}$ Dio obiteljske građe iz trogirske zbirke prodan je 1910. Zemaljskom arhivu u Zagrebu, gdje se nalazi i danas. ${ }^{6}$ Iako je trogirska zbirka tijekom vremena pretrpjela mnoge promjene u svojem sadržaju (uništenje/pljačka, prodaja vrijedne građe), ostala je sačuvana njezina knjižna građa, koja je katalogizirana 1960-ih. U isto vrijeme većina njezine arhivske i rukopisne građe prebačena je u Povijesni arhiv u Splitu na sređivanje i pohranu, ${ }^{7}$ a s njom i obiteljski spisi Fanfogna u fondu Obitelj Fanfogna-Garagnin.

Iako je fond trenutačno u rekonstrukciji te će se zasigurno mijenjati njegova postojeća struktura (posloženost i klasifikacija dokumenata), neophodno je ukratko izložiti zatečeno stanje u trenutku istraživanja. Pregledan je dio fonda koji sadržava veći broj različitih dokumenata koji se odnose na članove obitelji Fanfogna i drugih zadarskih plemićkih obitelji povezanih s njima. ${ }^{8}$ Dokumenti su složeni u zasebnim košuljicama smještenim u dvjema kutijama pod nazivom Genealoška stabla raznih obitelji 1. ${ }^{9}$ i Obiteljski spisi Fanfogna 1. Unutar

tar (Zadar: Državni arhiv u Zadru, 2007), 5 i 8, pristup ostvaren 7. 9. 2020., https://www.dazd.hr/ attachment/preview/5c657cc6b6fb9/dazd-349-corponese.pdf.

5 Nakon vjenčanja Antuna Fanfogna i Katarine Garagnin 1840. manji dio obiteljskoga arhiva dolazi iz Zadra u Trogir te postaje, zajedno s knjižnicom (arhivom) obitelji Garagnin (Trogir, 18. stoljeće), cjelovita obiteljska zbirka. Zbirka je sadržavala iznimno vrijedne knjige, rukopise i prijepise, uključujući i obiteljsku dokumentaciju s različitim spisima, poslovnim knjigama, zapisima, genealoškim prikazima. O zbirci, odnosno knjižnici Garagnin-Fanfogna (Muzej grada Trogira) vidi: Morović, „O trogirskoj knjižnici”, 95-106; Fani Cega, „Knjižnica Garagnin Fanfogna u Muzeju grada Trogira”, Informatica Museologica 29 (1998), br. 1-2: 52-59; „Arhivsko gradivo. Obitelj Fanfogna-Garagnin” (HDA). Dio obiteljskoga arhiva u Zadru bio je u posjedu Antunova brata Ivana Fanfogna. Obiteljski fond zaprimljen je i u Arhiv C. k. namjesništva u Zadru negdje između 1895. i 1905. godine. Morović, „O trogirskoj knjižnici”, 98; Cega, „Knjižnica Garagnin Fanfogna”, 53. Vidi detaljnije i: „Arhivsko gradivo. Obitelj Fanfogna” (DAZD).

6 Prodani dio obiteljske građe sadržavao je dio knjižnoga fonda, rukopisa i pergamena. Grof Ivan Dominik Fanfogna navodi se kao prodavatelj. „Arhivsko gradivo. Obitelj Fanfogna-Garagnin” (HDA).

7 Cega, „Knjižnica Garagnin Fanfogna”, 53-54; Morović, „O trogirskoj knjižnici”, 96, 102-105.

8 S obzirom na to da je fond trenutačno u postupku sređivanja, u ovom radu zabilježena su isključivo osobna zapažanja autora o njegovu sadržaju. Pregledani dio sadržava različite dokumente - genealoška stabla (crteži), kratke zapise, dijelove sačuvanih izvornih dokumenata (inventar, 1412.) itd. Veći broj sačuvanih dokumenata odnosi se na kasnije prijepise notarskih i pojedinih sudskih dokumenata koji sadržavaju podatke o članovima obitelji Fanfogna i ostalim zadarskim plemićima (12. - 16. stoljeće: oporuke /inventari/, priznanice, ugovori o kupoprodaji i koncesiji i sl.). Čini se da su pojedini prepisivači bili javni notari koji su djelovali u Zadru od 16. do 19. stoljeća (Šimun Budineus, Franjo Sorini, Šimun Lovatello, Domenico Castelli...), što će potvrditi buduća istraživanja ovoga fonda. Među tim spisima pronađeni su i neki zapisi koji izvorno pripadaju pojedinim notarima (Mihovil de Zandonatis, 16. stoljeće).

9 Prikazi genealoških stabala (crteži, kopije) članova obitelji Fanfogna te članova pojedinih zadarskih plemićkih obitelji (primjerice Soppe, Begna). Većina crteža nije potpisana i najvjerojatnije pripada kasnijem razdoblju (18. - 19. stoljeće). 
obiteljskih spisa nalaze se zasebno odvojeni svežnjići s različitim dokumentima (12. - 19. stoljeće). ${ }^{10}$

S njima je i zaseban svežnjić s petnaestak različitih prijepisa, većinom notarskih dokumenata, koji datiraju iz razdoblja od 1314. do 1397. godine. ${ }^{11}$ Prijepisi su djelo različitih prepisivača (većinom zadarskih notara) iz 17. i 18. stoljeća. ${ }^{12}$ Većina prijepisa označena je kao copia ili exemplum sumptum ${ }^{13}$ notarskih dokumenata iz različitih bilježničkih knjiga koje su u vrijeme prepisivanja bile pohranjene $\mathrm{u}$ Cancelleria della Magnifica communità di Zara. ${ }^{14}$

Među njima je pronađen i prijepis zapisnika inkvizicijskoga sudskog procesa održanog u vrijeme mletačke opsade Zadra (1345. - 1346.). ${ }^{15}$ Njegov je sadržaj važan zbog nekoliko razloga. Iako nije sačuvan u izvornom obliku, ipak je riječ o najstarijem poznatom sudskom zapisniku o inkvizicijskom postupku u sred-

10 Pregledani su sljedeći dokumenti u svežnjićima: prijepisi oporuka i dijelova inventara (12. - 16. stoljeće) u: Obiteljski spisi 1/I a; „Summario de Requisiti Diploma, Patenti e Ducali de servitii prestati alla Serenissima Republica di Venetia dagli Auttori del conte Francesco Fanfogna...” u: Obiteljski spisi 1/I b (13. - 17. stoljeće); crteži, privilegij (notar Ivan Filip Raymundus, 15. stoljeće), prijepisi notarskih dokumenata iz 14. i 15. stoljeća (kupoprodaja, dražbe, najam, oporuke i sl.) u: Obiteljski spisi 1/III; prijepisi notarskih dokumenata iz 14. stoljeća u: Obiteljski spisi 1/IV; kratki zapisi u Sumariji (15. stoljeće) u: Obiteljski spisi 1/V i prijepisi oporuka iz 14. i 15. stoljeća u: Fanfogna Testamentorum.

11 U ovom radu svežnjić se navodi na sljedeći način: HR-DAST-156, Obitelj Fanfogna-Garagnin, Obiteljski spisi Fanfogna 1 (dalje: Spisi 1), Prijepisi dokumenata (14. stoljeće) (dalje: Prijepisi).

12 U svežnjiću se nalaze većinom prijepisi notarskih dokumenata (oporuke, zamjena i kupoprodaja, priznanice itd.) i pojedinih sudskih spisa 14. stoljeća (notari: Nikola Sagarela, Konrad pok. Rangerija iz Padove, Petar de Serçana, Artikucije iz Rivignana, Vannes pok. Bernarda iz Ferma). Zapisani su različitim rukopisima, među kojima neki imaju i obilježja notara (potpis, notarski znak i sl.), što pokazuje da su ih načinili zadarski bilježnici 17. i 18. stoljeća (Franjo Sorini, Domenico Castelli, Šimun Lovatello itd.). Osim njihovih, u nekoliko prijepisa identificiran je i rukopis nepoznatoga prepisivača.

13 Sumptum (exemplum) označava prijepis teksta preuzet iz izvornoga dokumenta. Vidi: „Sumptum” (par les Bénédictins de St. Maur, 1733-1736), u: Carolus du Fresne Du Cange et al., Glossarium mediae et infimae latinitatis (Niort: L. Favre, 1883-1887), t. 7, col. 656a, pristup ostvaren 7. 9. 2020., http://ducange.enc.sorbonne.fr/SUMPTUM. Za termin copia / transumptum, exemplum vidi: Filippo Valenti, Scritti e lezioni di archivistica, diplomatica e storia istituzionale, Pubblicazioni degli Archivi di Stato Saggi 57 (Ministero per i beni e le attività culturali, Ufficio centrale per i beni archivistici, 2000), 286288.

14 U prijepisima se bilježi da su se te knjige nalazile u Cancelleria della Magnifica communità di Zara - pokrajinskoj kancelariji u kojoj su radili javni bilježnici u 17. stoljeću (a i poslije). Ured općinske kancelarije (... officio della canceleria della Communita...) bilježi se i u 16. stoljeću. Filip Novosel, „Društvene prilike i svakodnevlje Zadra u pozadini vojnih zbivanja za vrijeme Kandijskoga rata” (doktorska disertacija, Sveučilište u Zagrebu, 2018), 27; Serđo Dokoza, „Archivium comunis Jadre’ u XIV. stoljeću”, Radovi Zavoda za povijesne znanosti HAZU u Zadru 48 (2006): 222. Iako danas postoji fond Općine/Komune Zadar (12. stoljeće - 1797.) u Državnom arhivu u Zadru (HR-DAZD-19), spisi općinske kancelarije slabo su sačuvani. DAZD, „Vodič Državnog arhiva u Zadru. Općina Zadar”, pristup ostvaren 7. 9. 2020., http://dazd.hr/vodic/dazd-0019/.

15 U ovom radu navodi se kao: HR-DAST-156, Obitelj Fanfogna-Garagnin, Spisi 1, Prijepisi, Inquisitio (16. - 17. rujna 1345.). 
njovjekovnom Zadru, čiji se pravni aspekt analizira u ovom radu. Prepisani tekst zapisnika jedino je pisano svjedočanstvo o zadarskom kaznenopravnom sustavu u prvoj polovini 14. stoljeća, čiji podaci potvrđuju dosadašnje spoznaje o tim pitanjima u postojećoj zadarskoj historiografiji. Međutim, najveća vrijednost zapisnika leži u njegovu doprinosu postojećim saznanjima o događanjima u vrijeme mletačke opsade Zadra. Naime, sadržaj otkriva zajednički tajni plan mletačkih zapovjednika i firentinskoga plaćenika Uguiccionea Dellosti o zauzimanju Zadra „iznutra”, uz pomoć stranih plaćenika smještenih u gradu. S ciljem analize toga plana u radu se istražuju najnoviji podaci o vojno-političkom aspektu događanja u posljednjoj fazi mletačke opsade Zadra 1346. godine. Na temelju tih saznanja, uz dopunu sličnim podacima iz ostalih izvora, iznosi se vremenska i prostorna rekonstrukcija događanja opisanih u zapisniku. Osim utvrđivanja autentičnosti iznesenih podataka, rekonstrukcijom se željelo doći i do saznanja o planiranim metodama, subjektima i cilju izvršenja glavnoga zadatka, što je naposljetku jasnije definiralo i ulogu mletačkih vojnih dužnosnika i stranih plaćenika u planiranju i izvedbi dogovorenih ratnih djelovanja tijekom opsade Zadra.

\section{Izvor}

Prijepis je zapisan smeđom tintom na papiru, kurzivom ukrasnoga stila 18. stoljeća. Tekst nije cjelovit, a zapisan je na sveukupno tri i pol stranice koje nemaju numeraciju. Na prvoj stranici na lijevoj margini zapisana su dva komentara, različita po rukopisu i boji tinte. ${ }^{16}$ Prvi se odnosi na kratku bilješku o presudi koju je nepoznati prepisivač prepisao iz izvornoga teksta zapisnika. ${ }^{17}$ Ispod njega nalazi se drugi komentar, u kojem se bilježi datum i godina početka inkvizicijskoga sudskog procesa te uloga zadarskoga rektora Črne de Fanfogna u procesu. ${ }^{18}$ Riječ je o kasnijoj intervenciji u tekst prijepisa, kojoj pripada i nekoliko podcrtanih riječi na prvoj stranici teksta. ${ }^{19}$

\footnotetext{
16 HR-DAST-156, Obitelj Fanfogna-Garagnin, Spisi 1, Prijepisi, Inquisitio (16. - 17. rujna 1345.), prva stranica.

17 Komentar je zapisan istim rukopisom kao i tekst prijepisa. Sadržaj komentara vidi u Prilog 1. (str. $1)$.

18 Sadržaj komentara vidi u Prilog 1. (str. 1).

19 S obzirom na to da se rukopis i boja tinte razlikuju od prvoga komentara, nije riječ o prepisivaču nego o drugoj osobi. Riječi „Cernem de Fafogna” i „rectores Jadre” podvučene su žutom bojom na prvoj stranici prijepisa. Time se htjelo istaknuti ime važnoga člana obitelji Fanfogna, kao i važnost njegove političke funkcije u tom razdoblju. Kako se prijepis nalazio u obiteljskom arhivu Fanfogna, moguće je da se radi o nekome iz te obitelji. HR-DAST-156, Obitelj Fanfogna-Garagnin, Spisi 1, Prijepisi, Inquisitio (16. - 17. rujna 1345.), prva stranica.
} 
Usporedna analiza rukopisa kojim su zapisani prijepis zapisnika i nekoliko sličnih prijepisa unutar istoga ${ }^{20}$ i ostalih svežnjića ${ }^{21}$ pokazala je da pripada istom prepisivaču. Istim rukopisom zapisano je i osobno pismo Domenica Ignazija Frauenbergera (1712. - 1791.) pronađeno u svežnjiću s prijepisom zapisnika. ${ }^{22} \mathrm{Za}-$ ključnu potvrdu o njemu kao prepisivaču zapisnika i navedenih prijepisa donosi sadržaj toga pisma i njegov vlastoručni potpis (Domenico Bersich). ${ }^{23} \mathrm{U}$ prilog tome govori i podatak da je Frauenberger osobno vodio obiteljsku knjižnicu Fanfogna nakon svojega dolaska u Zadar. Osim njihove knjižnice i arhiva sređivao je građu u još nekoliko zadarskih samostanskih i privatnih arhiva. Ostao je zabilježen u historiografiji i kao prepisivač važnih zadarskih rukopisa i dokumenata (kartulari samostana Sv. Marije i sv. Krševana). ${ }^{24}$

Pismo je datirano 8. travnja 1767., u vrijeme kad je Frauenberger već dovršio sređivanje arhiva samostana Sv. Marije. ${ }^{25}$ Taj podatak govori da je i prijepis zapisnika mogao nastati u drugom dijelu 1760 -ih, kad je nastao još jedan njegov prijepis sačuvan u obiteljskim spisima. ${ }^{26}$ Sadržaj pisma potvrđuje njegov rad kao namještenika u komunalnom i bilježničkom arhivu. ${ }^{27}$ Frauenberger sređuje notarske dokumente i registar zadarskih bilježnika, koji su se u to vrijeme nalazili u Cancellaria della communità u Zadru. ${ }^{28}$ Također u pismu bilježi da je u „Notariato al Criminal de Rettori di Zara” naišao na spomen o zadarskom rektoru

20 Vidi ovdje bilj. 12. Ni ti prijepisi nemaju osobni potpis ili neka druga obilježja koja bi potvrdila identitet prepisivača. Iako su većinom zapisani istom tintom na papiru, neki su zapisani i tamnijom smeđom tintom. Vidi primjerice prijepise dokumenata iz 1314., 1316., 1362., 1370., 1391. i 1393. u: HRDAST-156, Obitelj Fanfogna-Garagnin, Spisi 1, Prijepisi.

${ }_{21}$ Istim rukopisom zapisano je još nekoliko prijepisa notarskih dokumenata unutar svežnjića Obiteljski spisi 1/III (npr. 1389., 1390.), Obiteljski spisi 1/IV (npr. 1358., 1391.), Obiteljski spisi 1/I a (prijepis 1289.). Vidi: HR-DAST-156, Obitelj Fanfogna-Garagnin, Spisi 1.

${ }_{22}$ U ovom radu navodi se kao: HR-DAST-156, Obitelj Fanfogna-Garagnin, Spisi 1, Prijepisi, pismo (8. travnja 1767.).

${ }^{23}$ Njegovo prezime/nadimak različito se bilježi u literaturi (Berčić, Bersić, Brčić, Bercich). Vidi detaljnije: Nikša Lučić, „Frauenberger”, Hrvatski biografski leksikon, mrežno izdanje, Leksikografski zavod „Miroslav Krleža”, pristup ostvaren 8. 10. 2020., https://hbl.lzmk.hr/clanak.aspx?id=6379.

${ }_{24}$ Lučić, „Frauenberger”. O Frauenbergerovu prijepisu rukopisa Obsidio Iadrensis, sačuvanom u Znanstvenoj knjižnici u Zadru, vidi: Miroslav Kurelac, Damir Karbić, „Uvod - Ljetopis 'Obsidionis Iadrensis Libri Duo', njegovo historiografsko i povijesno značenje”, u: Obsidio Iadrensis = Opsada Zadra, Monumenta spectantia historiam Slavorum Meridionalium 54, Scriptores VI, ur. Branimir Glavičić et al. (Zagreb: HAZU, 2007, dalje: Obsidio), 20.

25 Samostanski arhiv sređivao je tri godine (1762. - 1765.). U istom samostanu prepisivao je različite isprave te sastavljao registar i kazala po sadržajima. Franjo Rački, „Iztraživanja u pismarah i knjižnicah dalmatinskih", Rad JAZU 26 (1874): 166.

${ }^{26} \mathrm{Na}$ početku jednoga prijepisa zapisanog njegovim rukopisom stoji napomena pro memoria 1765. HR-DAST-156, Obitelj Fanfogna-Garagnin, Spisi 1, Obiteljski spisi 1/III.

27 Spomen o tome vidi i u: Lučić, „Frauenberger”.

28 Bilježi i da je pronašao notarske spise iz 1289., ali u lošem stanju. HR-DAST-156, Obitelj Fanfogna-Garagnin, Spisi 1, Prijepisi, pismo (8. travnja 1767.), prva stranica. 
Črni de Fanfogna iz vremena mletačke opsade Zadra (1345.), ${ }^{29}$ misleći pritom na izvorni sudski zapisnik, što ga ujedno potvrđuje kao njegova prepisivača. Čini se da pod navedenim nazivom Frauenberger općenito podrazumijeva sudski registar za kaznene predmete koji se u njegovo vrijeme još uvijek nalazio u općinskoj kancelariji Zadra. Međutim, kako kaže dalje u istoj rečenici, izgledno je da se izvorni zapisnik (a moguće i ostali slični dokumenti) nalazio u domu obitelji Fanfogna (... in casa...) u trenutku prepisivanja. Kako i sam kaže u svojim bilješkama, prijepise izvornih dokumenata o članovima obitelji Fanfogna namjeravao je arhivirati u zasebne obiteljske knjige. ${ }^{30}$ Iako ostaje nejasno kome je pismo upućeno, njegov ,izvještajni” stil pisanja o stanju obiteljske dokumentacije upućuje na nekoga važnog člana obitelji Fanfogna.

Prema Frauenbergerovoj bilješci na početku prijepisa, izvorni zapisnik nalazio se u registru zadarskoga kaznenog suda (... ex quaterno criminalium...). ${ }^{31}$ Riječ je o izgubljenom registru kaznenih predmeta u koji su se zapisivali kazneni procesi u srednjovjekovnom Zadru. ${ }^{32}$ Slični registri postojali su pod različitim nazivima i u drugim gradovima. ${ }^{33}$ Općenito, nijedan zadarski sudski registar za kaznene (i

29 ... stò poi trovato in Notariato al Criminal de Rettori di Zara trà quali Rettori uno Cerne Fanfogna in tempo dell'assedio di Zara del 1345 e quanti e quali sentenze di morte pronun (...) con processo di Zadarini delinquente... HR-DAST-156, Obitelj Fanfogna-Garagnin, Spisi 1, Prijepisi, pismo (8. travnja 1767.), prva stranica.

${ }^{30}$ HR-DAST-156, Obitelj Fanfogna-Garagnin, Spisi 1, Prijepisi, pismo (8. travnja 1767.), prva stranica. Pod pojmom casa Frauenberger podrazumijeva dom obitelji Fanfogna za koju prepisuje izvorne dokumente. Obiteljske knjige navodi u pismu kao ... libri per casa... i ... terzo libro delle carte di casa... HR-DAST-156, Obitelj Fanfogna-Garagnin, Spisi 1, Prijepisi, pismo (8. travnja 1767.), druga stranica.

${ }_{31}$ Exemplum sumptum ex quaterno criminalium processuum tempore obsidionis civitatis Iadre. HRDAST-156, Obitelj Fanfogna-Garagnin, Spisi 1, Prijepisi, Inquisitio (16. - 17. rujna 1345.), prva stranica.

32 Prema Popiću, zasebni registar za kaznene predmete u Zadru vjerojatno je postojao već krajem 13. stoljeća, slično kao i u Dubrovniku. Popić bilježi spomen toga registra u dva sudska spisa iz druge polovine 14. stoljeća: u dokumentu iz 1385. (quaternus criminalium, 1361.) i 1365. (quaternus denunciarum et accusationum). U Zadru je postojao i notar koji je vodio kaznene zapisnike od 1361. (notarius ad criminalia). Tomislav Popić, Krojenje pravde. Zadarsko sudstvo u srednjem vijeku (1358. - 1458.) (Zagreb: Plejada, 2014), 34, 54.

33 Ovisno o načinu vođenja dokumentacije, registri kaznenih predmeta različito su se nazivali u pojedinim gradovima (13. i 14. stoljeće). Primjerice, u Dubrovniku Liber de maleficiorum (ili Liber de maleficiis). U Perugii su se zasebno vodile knjige za akuzacijske i inkvizicijske postupke (libri accusationum / libri inquisitionum). Trogir je imao najstarije sačuvane kaznene registre u Dalmaciji - Liber litium et questionum criminalium et sententiarum, koji je sadržavao kaznene i civilne predmete (1281.). Nella Lonza, „Srednjovjekovni zapisnici dubrovačkog kaznenog suda: izvorne cjeline i arhivsko stanje", Anali Zavoda za povijesne znanosti HAZU u Dubrovniku 41 (2003): 48-49 (i bilj. 19), 56; Popić, Krojenje pravde, 34. U Bologni su se akuzacijski procesi zapisivali u Accusationes (1226. 1327.), a inkvizicijski u Libri inquisitionum et testium (1242. - 1532.). Diana Tura, „Archival Sources: Governmental, Judicial, Religious, Familial”, u: A Companion to Medieval and Renaissance Bologna, ur. Sarah Rubin Blanshei (Leiden; Boston: Brill, 2018), 32. O registrima u drugim talijanskim gradovima vidi: Didier Lett, „Gender, childhood and sexual violence in the judicial archives of fifteenth-century Bologna”, Clio. Women, Gender, History 42 (2015): 203 (bilj. 4). 
civilne) predmete nije ostao sačuvan za razdoblje prije $1350-$ ih. ${ }^{34}$ Sačuvan je tek ulomak kaznenih zapisnika za razdoblje 1411. - 1413. ${ }^{35}$ što Frauenbergerov prijepis zapisnika čini jedinim pisanim svjedočanstvom o zadarskom kaznenopravnom sustavu i inkvizicijskom sudskom postupku u prvoj polovini 14. stoljeća. U tom sačuvanom ulomku nalazi se i primjer zapisnika inkvizicijskoga postupka iz 1412. godine. ${ }^{36} \mathrm{Uz}$ taj primjer, tekst izvornoga zapisnika u prijepisu bilo je moguće usporediti i sa sličnim pravnim materijalom iz talijanskih komuna (13. - 15. stoljeće).

Izvorni tekst zapisnika u prijepisu podijeljen je na dva dijela (označena dvama različitim datumima). Na početku prvoga dijela navodi se godina i nadnevak početka postupka (1345. die 16 mensis septembris). ${ }^{37} \mathrm{~S}$ obzirom na to da je bilo uobičajeno da sudski kancelar upisuje uglavnom datume održavanja ročišta, a godinu i indikciju zapisivali su većinom uslijed njihove izmjene, ${ }^{38}$ izgledno je da Frauenberger sam unosi zapis godine pri izradi prijepisa.

${ }^{34}$ Iako su registri kaznenih predmeta izgubljeni, sačuvana je sudska dokumentacija srednjovjekovnih svjetovnih zadarskih sudova vezana za građansko, trgovačko i pomorsko pravo. Manji dio (presude građanskih sporova u obliku izdanih isprava) sačuvan je u Diplomatičkom zborniku i najstarijim notarskim registrima (13. i prva polovina 14. stoljeća). Najstariji zadarski sudski registar (građanske parnice) sačuvan je za razdoblje nakon „crne smrti” (1351. - 1353.). Gordan Ravančić, „Curia maior ciuilium - najstariji sačuvani registar građanskih parnica srednjovjekovnog Zadra (1351. - 1353.)”, Radovi Zavoda za povijesne znanosti HAZU u Zadru 43 (2001): 85-160. Dokumentacija zadarskih sudova druge polovine 14. i prve polovine 15. stoljeća pohranjena je u dvama arhivskim fondovima Državnoga arhiva u Zadru - Curia maior ciuilium i Curia consulum et maris. Popić, Krojenje pravde, 33-34. Arhivske fondove i dokumentaciju, kao i općenito temu zadarskoga sudstva u srednjovjekovnom Zadru, detaljno je istražio i o tome pisao Popić. Vidi: Tomislav Popić, „Srednjovjekovni zadarski kapitulari”, Povijesni prilozi 31 (2012), br. 42: 43-80; Tomislav Popić, „Izvorne cjeline srednjovjekovnih zadarskih sudskih zapisnika u arhivskom fondu Curia maior ciuilium", Historijski zbornik 64 (2011), br. 2: 321-376; Tomislav Popić, „Zadarski sud Curia maior ciuilium i njegovo djelovanje” (doktorska disertacija, Sveučilište u Zagrebu, 2011); Tomislav Popić, „Zadarska Curia consulum et maris i njezini zapisnici iz druge polovice 14. i prve polovice 15. stoljeća”, Povijesni prilozi 30 (2011), br. 41: 143-171.

35 U tom ulomku registra kaznenih predmeta sačuvani su primjeri akuzacijskoga i inkvizicijskoga sudskog postupka. Popić, Krojenje pravde, 54, 157-158. Sadržaj pojedinih zapisnika iz toga ulomka vidi u: Popić, Krojenje pravde, 217-222.

36 Primjer je datiran 24. kolovoza 1412. (istražni postupak zadarskoga kneza i savjetnika protiv Nikole pok. Ivana, optuženog za ubojstvo Jurja Ralice). Objavio ga je: Popić, Krojenje pravde, predmet br. 27, str. 222.

37 HR-DAST-156, Obitelj Fanfogna-Garagnin, Spisi 1, Prijepisi, Inquisitio (16. - 17. rujna 1345.), prva stranica.

38 Kako je Popić objavio samo pojedine zapisnike iz sačuvanoga registra za kaznene predmete (1411. - 1413.), nije moguće preciznije pratiti način bilježenja datuma u svim zapisnicima; vidi ovdje bilj. 35. Međutim, i u objavljenim zapisnicima bilježe se samo datumi održanih ročišta. Sličan način bilježenja datuma vidi i u pojedinim primjerima građanskih sporova: Popić, Krojenje pravde, 175-177, 222-226. Prema Popiću, sudski su notari pri datiranju sporova, presuda i ročišta koristili stil inkarnacije (početak godine 25. ožujka) i bedansku indikciju (izmjena 24. rujna svake godine); Popić, „Izvorne cjeline”, 328. S obzirom na to da se u zapisniku opisuju događaji iz rujna, notar ne bilježi godinu. 
U daljnjem tekstu ukratko se iznosi sadržaj optužnice. Na prvoj stranici teksta na lijevoj margini nalazi se i bilješka o presudi. Na isti način bilježile su se i presude u sačuvanim kaznenim zapisnicima iz 15. stoljeća. ${ }^{39}$ Način bilježenja početka procesa kao i presude na margini (u obliku bilješke) upućuje na sličnost u strukturi zapisnika iz 1346. i 1412. u Zadru, što svjedoči o tome da su se zapisnici iz inkvizicijskoga postupka vodili na istovjetan način i tijekom druge polovine 14. stoljeća.

Sljedećega dana (Die 17. mensis predicti) održava se novo ročište, kako je i zapisano na dnu prve stranice. Druga stranica započinje uvodnim dijelom u kojem se ukratko opisuje kako je sud optuženika ispitao i stavio na muke radi dobivanja istinitoga iskaza. Nakon mučenja optuženik iznosi svoje priznanje, koje je zapisano na dvije i pol stranice..$^{40} \mathrm{U}$ završnom dijelu tekst se prekida u naraciji, što upućuje na moguće oštećenje izvornoga zapisnika ili nemogućnost prepisivača da ga prepiše u cijelosti.

Jezik i stil prepisanoga zapisnika odgovaraju „kancelarijskom” jeziku specifičnom za zadarske notare 14 . stoljeća, ${ }^{41}$ koji su uz građanske vodili i kaznene spise srednjovjekovnih zadarskih svjetovnih sudova. ${ }^{42}$ Kako je poznato da su i zadarski notari sastavljali pravne dokumente prema tadašnjim zbirkama formulara, ${ }^{43}$ moguće je da su postojali pravni predlošci prema kojima su sastavljali i kaznene spise. ${ }^{44} \mathrm{Na}$ to upućuje niz sličnosti u strukturi teksta i korištenim pravnim

39 Vidi ovdje bilj. 17. Sličan način bilježenja presude u zadarskim zapisnicima iz akuzacijskoga i inkvizicijskoga postupka u 15. stoljeću vidi u: Popić, Krojenje pravde, predmet br. 25 (str. 219) i br. 27 (str. 222).

40 HR-DAST-156, Obitelj Fanfogna-Garagnin, Spisi 1, Prijepisi, Inquisitio (16. - 17. rujna 1345.), druga, treća i četvrta stranica.

${ }^{41}$ Iako je zadarski notarijat koristio pravna, a s tim i jezična rješenja tadašnjih pravnih formulara (uglavnom bolonjske škole), ipak rano razvija vlastiti specifični uzus (jezični stil, pisanje pravnih formulacija, arhaizme u izričaju i sl.). Branka Grbavac, „Notarijat na istočnojadranskoj obali od druge polovine 12. do kraja 14. stoljeća" (doktorska disertacija, Sveučilište u Zagrebu, 2010), 322-323.

$42 \mathrm{~S}$ obzirom na to da su zadarski sudski notari vodili zajedno i građanske i kaznene spise krajem 1350-ih, slična praksa postojala je zasigurno i sredinom 1340-ih. Popić bilježi da je sudski notar Konrad Rangerijev iz Padove notarius ad ciuilia et criminalia vodio i građanske i kaznene spise 1358. godine. Razdvajanjem građanske i kaznene sudbenosti početkom 1361. započinje novi način vođenja sudskih spisa - dva notara (notarius ad ciuilia i notarius ad criminalia), birana od Velikoga vijeća, zasebno vode registre građanskih sporova i kaznenih predmeta. Postojao je i treći notar, koji je vodio zapisnike Sudbenoga dvora konzula i mora (notarius curie consulum). Popić, Krojenje pravde, 36-37.

${ }_{43}$ Zbirke formulara sadržavale su predloške prema kojima su notari sastavljali pravne dokumente, što je vidljivo po njihovu sadržaju i korištenju specifičnih pravnih formulacija, ovisno o pravnom poslu. Tijekom 13. stoljeća pojavilo se više takvih zbirki, većinom na području Bologne, od kojih je najpoznatija Summa artis notariae bolonjskoga profesora Rolandina Pasagerijeva (1255./1256.). Grbavac, „Notarijat na istočnojadranskoj obali”, 78-80, 323. O korištenju formulara kod zadarskih notara vidi i: Branka Grbavac, „Svjedočanstvo o stvarnosti ili fikcija - zadarski notari između formulara i prakse", Acta Histriae 19 (2011), br. 3: 393-406.

${ }_{44}$ Nije poznato prema kojim su formularima ili pravnom predlošku sastavljali zapisnike kaznenih predmeta u Zadru (14. stoljeće). Rolandin Pasagerijev bilježi upute o sastavljanju libellorum (i sudske 
formulacijama između prepisanoga zadarskog zapisnika i pojedinih zapisnika iz inkvizicijskoga postupka u Bologni (Emilia Romagna), ${ }^{45}$ Lombardiji (Brescia) ${ }^{46} \mathrm{i}$ Umbriji (Perugia) ${ }^{47}$ krajem 13. i u prvoj polovini 14. stoljeća. Sličan tip zapisnika javlja se i u Reggio Emiliji (1373.), ${ }^{48}$ a zadržao se u Zadru i Bologni i tijekom prve polovine 15. stoljeća. ${ }^{49}$

\section{Sadržajna analiza - pravni i vojno-politički aspekt}

Sadržaj zapisnika pruža dragocjene podatke o povijesti Zadra u vrijeme mletačke opsade grada. Različitost tih podataka proizlazi iz pravnoga i vojno-političkoga aspekta teksta, utvrđenih obradom i prijevodom latiničnoga teksta. ${ }^{50}$ Međutim, podaci o osobama i događajima u prijepisu zapisnika odgovaraju osobama i kontekstu događanja 1346., što je zabilježeno u više različitih izvora.

dokumentacije). Za njegove upute za suce, i u civilnim i u kriminalnim procesima, vidi prvi dio Tertia pars summae notariae, pogl. 9 (De Iudiciis et ordine Iudiciorum), u: Rolandinus Passagerii, Svmma artis notariae Do. Rolandini Rodvlphini Bononiensis [... ](Lvgdvni: Apud haeredes Iacobi Iuntae, 1559), 571-684. U drugom dijelu istoga poglavlja Rolandin daje i upute u kakvoj formi pisati civilne i kaznene zapisnike. Passagerii, Svmma artis notariae, 684-716. Treći dio odnosi se isključivo na rad sudaca. Passagerii, Svmma artis notariae, 716-742. Međutim, kad se osvrće na sastavljanje različitih pravnih zapisa, ne spominje izričito kaznene spise. Passagerii, Svmma artis notariae, pogl. 10, 742-785.

45 Primjer istražnoga postupka za počinjenu krađu u Bologni 1299. bilježe u svojim studijama Pennington i Maffei prema izdanju Kantorowicza (o djelu Alberta Gandina de Crema). Albert Gandino bio je školovani pravnik i sudac te autor poznatoga traktata pod nazivom Libellus de maleficiis (Tractatus de maleficiis). Općenito o Albertu Gandinu vidi: Massimo Vallerani, Medieval Public Justice (Washington, D. C.: The Catholic University of America Press, 2012), 7, 44-47. O istražnom postupku (Bologna), uz obrazloženje autora, vidi: Kenneth Pennington, „Introduction to the Courts”, u: The History of Courts and Procedure in Medieval Canon Law, ur. Wilfried Hartmann i Kenneth Pennington (Washington, D. C.: The Catholic University of America Press, 2016), 10-18 (i bilj. 27). Maffei bilježi sadržaj prvoga dijela zapisnika u kojem se iznosi optužnica. Elena Maffei, Dal reato alla sentenza. Il processo criminale in età comunale (Rim: Storia e Letteratura, 2005), 85. Transkripciju izvornoga zapisnika iz Bologne vidi u cijelosti: Hermann U. Kantorowicz, ur., Albertus Gandinus und das Strafrecht der Scholastik (Berlin: J. Guttentag Verlagsbuchhandlung, 1907), dok. 21, str. 203-218.

${ }_{46}$ Primjer istrage koju su proveli izaslanici cara Henrika VII. u Brescii 1313./1314. godine. Wilhelm Doenniges, Acta Henrici VII. imperatoris Romanorum et monumenta quaedam alia medii aevi, Pars I (Berolini, 1839), 165-180.

${ }_{47}$ Primjer istrage o zaposjedanju komunalnoga zemljišta Perugie u gradiću Chiugi (braća Glutol i Tankredo, sinovi gospodara Sensi) 1291. godine. Massimo Vallerani, „Il Liber terminationum del comune di Perugia”, Mélanges de l'Ecole française de Rome. Moyen-Age, Temps modernes 99 (1987), br. 2: 660 (dok. 42), 688-698.

48 Vidi prijevod i transkripciju dokumenta od 16. lipnja 1373. godine: Joanna Carraway Vitiello, Public Justice and the Criminal Trial in Late Medieval Italy: Reggio Emilia in the Visconti Age (Leiden; Boston: Brill, 2016), 56-57 (bilj. 10).

${ }^{49}$ Objavljeni zapisnik iz Zadra (1412.), vidi ovdje u bilj. 36. Bologna: libellus suđenja za silovanje dvoje djece u svibnju 1435. godine. Lett, „Gender, childhood and sexual violence”, 200-212.

50 Cjelovitu transkripciju teksta vidi na kraju rada, Prilog 1. (str. 1-4). 
U uvodnom dijelu teksta navodi se da inkvizicijski postupak pokreću po službenoj dužnosti, na osnovi javnih glasina, trojica zadarskih rektora: Črne de Fanfogna, Tomas, sin Benedikta de Matafaris, i Damjan, sin Filipa de Begna. Istraga je pokrenuta protiv Uguiccionea Dellosti, sina gospodara Janija de comitibus de Gala Cagalandi iz Firence. ${ }^{51}$ Riječ je o relativno nepoznatom firentinskom plemiću ${ }^{52}$ čije uhićenje u Zadru bilježi i autor Obsidio Iadrensis: „Neki Toskanac s opakim naumom i još gorom odlukom da ga provede u djelo prebjegne iz mletačke vojske u Zadar, kojeg po nalogu rektorā Zadrani uhvate." 53 Taj događaj bilježi se u dijelu između 10. rujna i 1 . listopada $1346 .,{ }^{54}$ što potpuno odgovara datumima, ali ne i godini ročišta koju bilježi Frauenberger. Sadržaj ovoga zapisa identičan je profilu optuženika i optužbama za koje ga se tereti u daljnjem tekstu zapisnika, što potvrđuje da se radi o istom slučaju zapisanom u dvama različitim izvorima. $\mathrm{U}$ prilog postavljenoj dataciji svjedoče i podaci o trojici rektora koji se navode $\mathrm{u}$ dva notarska dokumenta, datirana 18 . rujna i 1 . listopada 1346 . godine. ${ }^{55} \mathrm{Ti}$ dokumenti dokazuju da su spomenuti rektori obavljali zajednički mandat upravo u tom razdoblju, ne 1345. godine. ${ }^{56}$

51 HR-DAST-156, Obitelj Fanfogna-Garagnin, Spisi 1, Prijepisi, Inquisitio (16. - 17. rujna 1345.), prva stranica.

52 „Cagalandi”, kako se bilježi u zapisniku, odgovara prezimenu Gangalandi. Riječ je o staroj firentinskoj plemićkoj obitelji koja je nosila prezime prema istoimenom lokalitetu na glavnom obiteljskom posjedu. Obitelj je imala velike posjede i utvrde u okolici gradova Settimo i Signa. Više o njima vidi: Arnaldo D’Addario, „Gangalandi, di”, Enciclopedia Dantesca, pristup ostvaren 24. 10. 2020., www.treccani.it/enciclopedia/di-gangalandi_(Enciclopedia-Dantesca); Jacopo Paganelli, „Et fuit de Scolaribus de Florentia'. Un profilo di Alberto vescovo di Volterra (1261-69)", Rassegna volterrana XCIII (2016): 131, 138, 147-149, 151-152 (bilj. 71), 154; Emanuele Repetti, ur., Dizionario geografico fisico storico della Toscana, sv. 2 (Firenze: coi Tipi di A. Tofani, 1835), 396-398; Edoardo Manarini, I due volti del potere: una parentela atipica di ufficiali e signori nel regno italico (Milano: Ledizioni, 2016), 134-135, 192-193. Ljude iz toga područja često se tako zapisivalo i u kasnijim dokumentima: „Sebastianus Ioannis Mariae de Comitibus de Gangalandi”. Giovanni Targioni Tozzetti, Relazioni D’Alcuni Viaggi Fatti In Diverse Parti Della Toscana Per Osservare Le Produzioni Naturali, E Gli Antichi Monumenti Di Essa, sv. 12 (Firenze: Cambiagi, 1779), 180.

${ }_{53}$ Obsidio, knj. 2, pogl. 17, str. 272.

54 Obsidio, knj. 2, pogl. 16, str. 270 i pogl. 17, str. 272.

55 Črne de Fanfogna, Tomas, sin Benedikta de Matafaris, i Damjan, sin Filipa de Begna. Vidi: Tadija Smičiklas, ur., Codex diplomaticus regni Croatiae, Dalmatiae et Slavoniae = Diplomatički zbornik Kraljevine Hrvatske, Dalmacije i Slavonije, sv. 11 (dalje: CD 11) (Zagreb: JAZU, 1913), dok. 247, str. 326 (18. 9. 1346.); Robert Leljak, ur., Inventari fonda Veličajne općine zadarske 1325. - 1385. (dalje: MCI 1) (Zadar: Državni arhiv u Zadru, 2006), dok. 12, str. 136 (1. 10. 1346.).

56 U notarskom dokumentu od 17. rujna 1345. među trojicom zadarskih rektora bilježi se jedino Tomas, sin Benedikta de Matafaris. Preostala dvojica bili su Pavao de Varicassis i Nikola de Vitcor. CD 11, dok. 178, str. 229. 


\section{Pravni aspekt}

Pravni aspekt ovoga teksta određuju vrsta dokumenta i pravna terminologija koju je zapisao sudski notar u inkvizicijskom postupku. Kako nisu sačuvani slični zadarski dokumenti za 14. stoljeće, tekst pruža dragocjen uvid u strukturu inkvizicijskoga kaznenog procesa i način funkcioniranja kaznenoga suda u izvanrednim ratnim okolnostima.

Prvi dan zapisa (16. rujna) odnosi se na pokretanje inkvizicijskoga postupka i čitanje optužnice. ${ }^{57}$ Dokument je sudski zapisnik u kojem je zapisan inkvizicijski postupak (inquisitio), ${ }^{58}$ pokrenut po službenoj dužnosti prema ovlastima trojice rektora (... ex eorum officii arbitrio...), ${ }^{59}$ a na temelju postojećih javnih glasina (... fama publica precedente...), ${ }^{60}$ što je uobičajena formulacija za pokretanje inkvi-

57 HR-DAST-156, Obitelj Fanfogna-Garagnin, Spisi 1, Prijepisi, Inquisitio (16. - 17. rujna 1345.), prva stranica.

58 U Europi, pa i u nas, postojala su dva tipa kaznenoga postupka u srednjem vijeku - akuzacijski i inkvizicijski (13. - 15. stoljeće). Postojalo je i više modela unutar istoga tipa postupka, pa čak i mješoviti tipovi. Razlike među njima odnose se uglavnom na način pokretanja tužbe (privatno/službeno), proceduru i težinu zločina. Inkvizicijski postupak pokretao se uvijek po službenoj dužnosti, i to najčešće za teže oblike zločina (posebno one koji su ugrožavali javni red i mir te sigurnost zajednice). Istragom se nastojalo riješiti zločin za koji je postojala i propisana kazna (novčana kazna, zatvor, kazna tjelesnoga ozljeđivanja ili smrtna kazna). O navedenom, kao i primjere Dubrovnika i talijanskih komuna (npr. Bologna, Savona), vidi: Nella Lonza, „Pred gosparom knezom i njegovim sucima...': Dubrovački kazneni postupci s početka XIV. stoljeća", Anali Zavoda za povijesne znanosti HAZU u Dubrovniku 30 (1992): 39, 52; Nella Lonza, „Tužba, osveta, nagodba: modeli reagiranja na zločin u srednjovjekovnom Dubrovniku", Anali Zavoda za povijesne znanosti HAZU u Dubrovniku 40 (2002): 58, 62, 68-69, 74-75, 101; Sarah Rubin Blanshei, Politics and Justice in Late Medieval Bologna (Leiden; Boston: Brill, 2010), 314-315; Trevor Dean, Crime and Justice in Late Medieval Italy (Cambridge: University Press, 2007), 7, 22-24, 36-38; Lett, „Gender, childhood and sexual violence”, 204; Vallerani, Medieval Public Justice, 35-47; Sarah Rubin Blanshei, Sara Cucini, „Criminal Justice and Conflict Resolution”, u: A Companion to Medieval and Renaissance Bologna, ur. Sarah Rubin Blanshei (Leiden; Boston: Brill, 2018), 336-337, 350-352.

59 Vallerani, Medieval Public Justice, 36-40, 49; Massimo Vallerani, „Criminal Court Procedure in Late Medieval Bologna: Cultural and Social Contexts", u: Violence and Justice in Bologna 1250-1700, ur. Sarah Rubin Blanshei (Lanham; Boulder; New York; London: Lexington Books, 2018), 39; Goran Tomašević, Antonija Krstulović Dragičević, Marija Pleić, „Pravni položaj okrivljenika u kaznenom postupku dalmatinskih statuta”, Hrvatski ljetopis za kazneno pravo i praksu 21 (2014), br. 1: 85; Lonza, „Tužba, osveta, nagodba”, 68; Carraway Vitiello, Public Justice, 58.

${ }^{60}$ Fama ili publica fama (javno znanje/glasine o ulozi optuženika u zločinu i samom zločinu). Carraway Vitiello, Public Justice, 54-55, 57, 88-89; Giorgos Plakotos, „Rumours, Gossip and Crypto-Jewish Identity in the Sixteenth-Century Venetian Inquisition", Annali della Scuola Normale Superiore di Pisa. Classe di Lettere e Filosofia 1, Inquisizioni (2009), br. 2: 426. Bez obzira na prijavitelja („denuncijanta”), sudac (ili neka službena osoba) mogao je pokrenuti službenu istragu već na osnovi postojećih glasina ili notornosti djela. Dean, Crime and Justice, 18, 24, 26; Vallerani, Medieval Public Justice, 36, 56-58; Trevor Dean, „Criminal Justice in mid fifteenth-century Bologna”, u: Crime, Society and the Law in Renaissance Italy, ur. Trevor Dean i K. J. P. Lowe (Cambridge: University Press, 1994), 19-21; Tomašević, Krstulović Dragičević, Pleić, „Pravni položaj okrivljenika”, 86-87. 
zicijskoga postupka (13. - 15. stoljeće) ${ }^{61}$ Iako se u optužnici neizravno navodi da je riječ o svojevrsnoj izdaji ${ }^{62}$ prema sastavljenim optužbama može se zaključiti da je u očima suda definitivno riječ o teškom zločinu koji ugrožava sigurnost te politički i pravni poredak komune, posebice u tadašnjim ratnim uvjetima.

Optuženika se tereti za suradnju s neprijateljem i počinjenje teških djela koja su za cilj imala predaju grada Zadra. Navodi se da su Uguiccionea zaveli neprijatelji i mrzitelji Zadra, Mlečani i njihov zapovjednik glavne kopnene utvrde (stikata), u čije je ime trebao počiniti određena zlodjela radi osvajanja grada. Naime, optužuje ga se da je, došavši iz mletačke utvrde, nezakonito i bez dozvole ušao u grad Zadar da bi podmitio nekolicinu zadarskih plaćenika. Njihov zadatak bio je osvojiti gradske utvrde, odnosno pojedine kule (i utvrđenja) na gradskim zidinama te ih predati Mlečanima, odnosno njihovu zapovjedniku glavne utvrde izvan grada. Međutim, pročulo se da je optuženik imao i druge planove za nanošenje štete gradu, što bi pridonijelo izolaciji grada te naposljetku i njegovoj predaji Mlečanima.

Na kraju iznošenja optužnice bilježi se i skraćena pravna formulacija (Super quibus omnibus et singulis dependentibus, coherentibus...) koja je u sličnim inkvizicijskim zapisnicima najčešće označavala tko je proveo istragu te da je nužno donijeti odgovarajuću presudu, odnosno kaznu prema postojećem normativnom okviru, najčešće statutu ili nekoj zasebnoj zbirci propisa, ${ }^{63}$ što je vjerojatno i ovdje bio slučaj. No izvori koji svjedoče o normativnom okviru za kazneno procesno pravo nisu ostali sačuvani za zadarsko srednjovjekovlje. Za razliku od ostalih dalmatinskih gradova, zadarski statut iz 1305. ne sadržava odredbe iz kaznenoga prava ni odredbe o ovlastima najviših gradskih službenika ili zadarskom

${ }_{61}$ Vallerani, Medieval Public Justice, 36; Dean, „Criminal Justice”, 19. O inkvizicijskom sudskom postupku i njegovu uvođenju u sudsku praksu svjetovnih sudova dalmatinskih gradova od 13. stoljeća vidi više u: Tomislav Popić, „The Fourth Lateran Council and the Functioning of Courts in Thirteenth Century Eastern Adriatic", u: The Fourth Lateran Council: An Event That Transformed Europe, ur. Ivan Majnarić, Daniel Patafta i Marko Jerković (Zagreb: Kršćanska sadašnjost et al., 2019), 36-46.

${ }^{62}$... potenti manu proditorie... HR-DAST-156, Obitelj Fanfogna-Garagnin, Spisi 1, Prijepisi, Inquisitio (16. - 17. rujna 1345.), prva stranica.

${ }^{63}$ Slična formulacija zapisana je i u bolonjskom dokumentu iz 1299. godine: Super quibus omnibus et singulis et quolibet predictorum et aliis dependentibus, descendentibus, coherentibus et conexis predictis vel alicui predictorum dictus $d$. potestas sub examine dicti iudicis inquirit et inquirere intendit et predictos vel aliquem ex eis repertum vel repertos culpabilem aut culpabiles de predictis vel aliquo predictorum punire et condempnare secundum formam statutorum et ordinamentorum, provisionum et reformationum comunis et populi civitatis Bononie et omni modo et iure quibus melius poterit. Maffei, Dal reato alla sentenza, 85. Sličnu formulaciju vidi i u istrazi Ivana de Levalossis, potestata Montefeltro, u ime Crkve iz 1360. godine (kazna/presuda prema konstitucijama svete rimske Crkve). Istraga je provedena protiv ... homines, universitates et Comunia Castrorum et Terrarum... Melchiorre Delfico, Memorie storiche della Repubblica di San Marino. Appendice (Milano: Dalla Tipografia di Francesco Sonzogno di Gio. Battista, 1804), br. XIX, str. XXXVII-XXXVIII. 
kaznenom sudu ${ }^{64}$ Prema mišljenju T. Popića, razlog tome valja potražiti u postojanju zasebnih zbirki propisa (kapitulara) koji su regulirali rad najviših gradskih službi, odnosno uprave (knez, rektori, suci, vijećnici, egzaminatori), a moguće i kaznenoga suda u 14. stoljeću. ${ }^{65}$ Osim kapitulara zadarskoga i paškoga kneza, ostali kapitulari nisu sačuvani. ${ }^{66}$

Optužbe koje se iznose na teret optuženika rezultat su indicija nastalih na temelju javnih glasina o navedenim zlodjelima (... et quod de predictis omnibus est publica vox et fama), ${ }^{67}$ što je ponekad bilo dovoljno za pokretanje službene istrage ili čak i presudu, ${ }^{68}$ posebice za teže zločine. Međutim, ovaj podatak može biti višeznačan - ili je optuženik bio već otprije poznat zadarskim vlastima (i javnosti) ili ga je netko prijavio vlastima neposredno prije izvršenja planiranih aktivnosti (nakon ulaska u grad). ${ }^{69}$ Optuženika su uhitili u gradu, najvjerojatnije \begin{tabular}{l}
\hline 64 Odnosi se na pročišćeni tekst zadarskoga statuta. Vidi objavljeni tekst drugoga latinskog izdanja u \\
hrvatskom prijevodu (na temelju izvornika iz 1564. i jedinoga sačuvanoga latinskog rukopisa koji se \\
čuva u Knjižnici samostana Male braće u Dubrovniku). Josip Kolanović, Mate Križman, ur., Statuta \\
Iadertina = Zadarski statut (Zadar: Ogranak Matice hrvatske u Zadru; Hrvatski državni arhiv, 1997), \\
9-10. Vidi: Šime Batović, „Predgovor”, u: Kolanović, Križman, Statuta Iadertina, 7. O izostanku nave- \\
denih odredbi vidi: Popić, Krojenje pravde, 113; Ivan Beuc, „Statut zadarske komune iz 1305. godine”, \\
Vjesnik historijskih arhiva u Rijeci i Pazinu 2 (1954): 674. Statuti pojedinih dalmatinskih gradova \\
sadržavali su odredbe kaznenoga prava. O kaznenom postupku u statutima nekih od njih (Split, Tro- \\
gir, Brač, Hvar, Korčula) vidi: Tomašević, Krstulović Dragičević, Pleić, „Pravni položaj okrivljenika”, \\
77-108; Lujo Margetić, „O nekim osnovnim značajkama pokretanja kaznenog postupka u srednjovje- \\
kovnim dalmatinskim gradskim općinama”, Hrvatski ljetopis za kazneno pravo i praksu 5 (1998), br. \\
1: 393-400, 408-416, 420-422.
\end{tabular}

${ }_{65}$ Prema Popiću, kapitulari (capitularia) zbirke su propisa koje su regulirale ustroj i nadležnosti (ovlasti), odnosno prava i obveze najviših gradskih službi i uprave. Popić napominje da je postojalo više takvih kapitulara u srednjovjekovnom Zadru, među kojima i Kapitular rektora (Capitulare dominorum rectorum), čije se postojanje bilježi već oko 1358. godine. Navodi i Brunellijevu tezu prema kojoj je postojao zasebni kapitular kaznenoga suda (capitulare per la curia criminale), kao i otkriće A. Teje o bilješci u zapisnicima zadarskoga CMC-a koja svjedoči o postojanju jedinstvene zbirke kapitulara (volumen statutorum Iadre i volumen capitularium Iadre). Popić, Krojenje pravde, 113-120. Detaljnije o kapitularima vidi i: Popić, „Srednjovjekovni zadarski kapitulari”, 43-80.

${ }_{66}$ Od svih zadarskih kapitulara za koje se smatra da su postojali sačuvana su samo dva - zadarskoga kneza iz 1278. (izvornik, u knjižnici Marciani u Veneciji) i paškoga kneza iz 1372. (prijepis Ivana Lučića). Popić, Krojenje pravde, 113-114.

${ }_{67}$ Usp. Dean, Crime and Justice, 26; Lonza, „Tužba, osveta, nagodba”, 71; Dean, „Criminal Justice”, 17, 19; Blanshei, Politics and Justice, 19; Carraway Vitiello, Public Justice, 57, 89. Termin publica fama vidi i u: Laura Ikins Stern, „Public Fame in the Fifteenth Century”, The American Journal of Legal History 44 (2000), br. 2: 198-222.

68 Lonza, „Pred gosparom knezom”, 38-39; Dean, „Criminal Justice”, 20-21. Prema Carraway Vitiello, ako u tekstu optužbe stoji formulacija publica fama bez navođenja imena tužitelja, ,javnost ili zajednica" preuzima ulogu tužitelja, a fama je njezin glas u tom inkvizicijskom postupku. Carraway Vitiello, Public Justice, 57.

${ }^{69}$ Prijavu su mogle podnijeti različite osobe, službene i privatne. U pojedinim slučajevima bile su propisane čak i novčane nagrade za građane koji bi prijavili zločin (vidi Dubrovnik). Lonza, „Tužba, osveta, nagodba", 70-71. 
gradska straža, na temelju čega je odmah započela službena istraga. ${ }^{70} \mathrm{~S}$ obzirom na to da u zapisniku stoji da je službena istraga započela na temelju javne glasine, prijavitelj najvjerojatnije nije ni postojao. ${ }^{71} \mathrm{U}$ samom procesu ne spominju se ni svjedoci optužbe, koji su često davali iskaze u kaznenom postupku. ${ }^{72}$ Postoji nekoliko mogućih razloga izostanka njihova spominjanja u tekstu. Kako se radi o izvanrednim okolnostima u vrijeme suđenja (opsada grada), moguće je da je vlast htjela ubrzati proces, pa i zaštititi moguće svjedoke od mletačke odmazde. ${ }^{73}$ Možda su svjedoci tajno dali iskaze, ali taj dio dokumenta nedostaje u prijepisu. ${ }^{74}$ Naposljetku, svjedoka možda i nije bilo, stoga je primijenjeno dokazivanje torturom, kako se i navodi u zapisu sljedećega dana (17. rujna). ${ }^{75}$

U drugom dijelu teksta opisuje se tijek istrage - kazneni sud provodi postupak ispitivanja (i mučenja) optuženika kojim se željelo dobiti njegovo priznanje, što je naposljetku zabilježeno u obliku cjelovitoga iskaza. Tekst započinje izjavom da je sud, sastavljen od rektora, zasjedao (... pro tribunali sedentibus...) u dvorani Nadbiskupske palače. ${ }^{76}$ Isti sud vodi inkvizicijski postupak, odnosno ispitivanje optuženika (... interrogatus ab eisdem dominis rectoribus...) na početku ročišta.

\footnotetext{
${ }^{70}$ Autor Obsidio Iadrensis bilježi da su ga uhitili Zadrani. Obsidio, knj. 2, pogl. 17, str. 272. Vidi slične primjere i za talijanske gradove u: Ikins Stern, „Public Fame”, 201.

${ }^{71}$ Inkvizicijski postupak po službenoj dužnosti (ex officio) pokretao se na temelju prijave ili javne glasine, kako se često i navodi u inkvizicijskim zapisnicima. Popić, „The Fourth Lateran Council”, 38.

72 Prema Popiću, u kaznenom postupku tvrdnje se dokazuju iskazima svjedoka, za razliku od građanske parnice. Popić, Krojenje pravde, 158. Vidi i: Carraway Vitiello, Public Justice, 123; Dean, Crime and Justice, 22. Prema sudskom materijalu za pojedine dalmatinske gradove Lonza zaključuje da je institut svjedoka važno dokazno sredstvo u kaznenim postupcima te ističe i važnost odlučivanja suda o „dopustivosti i prihvatljivosti” iskaza svjedoka u dokaznom postupku. Lonza, „Pred gosparom knezom"', 41. Iako su svjedočenja bila veoma važna u oba tipa kaznenoga postupka (svjedoci optužbe/ obrane), postojale su i iznimke unutar inkvizicijskoga procesa - u pojedinim slučajevima istraga je provedena bez svjedoka, na osnovi glasina o zločinu i priznanja optuženika pod torturom. Takvi primjeri bilježe se u istragama protiv stranaca, marginalaca i plaćenika u gradovima, kojima su i češće dosuđivane strože kazne. Blanshei, Politics and Justice, 363; Dean, „Criminal Justice”, 22, 26-27; Carraway Vitiello, Public Justice, 176.
}

73 Zaštita identiteta svjedoka u vrijeme opsade grada bilježi se i kod autora Obsidio Iadrensis. Naime, sam autor bio je svjedokom ratnih događanja koja opisuje u svojem djelu i namjerno skriva vlastiti i identitet naručitelja. Obsidio, knj. 1, pogl. 2, str. 118. Promišljanja o autoru vidi i u: Kurelac, Karbić, „Uvod - Ljetopis”, 12-19. O anonimnim prijavama „denuncijanata” radi zaštite identiteta u Firenci (14. stoljeće): Andrea Zorzi, „The judicial system in Florence in the fourteenth and fifteenth centuries”, u: Crime, Society and the Law in Renaissance Italy, ur. Trevor Dean i K. J. P. Lowe (Cambridge: University Press, 1994), 44.

74 Usp. Dean, Crime and Justice, 18.

75 HR-DAST-156, Obitelj Fanfogna-Garagnin, Spisi 1, Prijepisi, Inquisitio (16. - 17. rujna 1345.), druga stranica.

${ }^{76}$ Među najvećim palačama u Zadru, važno duhovno (i upravno) središte srednjovjekovne komune Zadra. U palači su odsjedali mnogi dostojanstvenici (papa Aleksandar III. 1177.; po potrebi i mletački dužd). Spominje se i kao mjesto zasjedanja vijeća u 14. stoljeću. Pavuša Vežić, „Nadbiskupska palača u Zadru", Peristil 22 (1979): 17-18. 
Nadležnost u rješavanju kaznenih (i civilnih) predmeta u ranijim razdobljima mletačke vlasti nad Zadrom, u 13. i prvoj polovini 14. stoljeća, imali su mletački knez i savjetnici (ili suci). ${ }^{77}$ Iako ne postoji mnogo podataka o zadarskom kaznenom sudstvu od 1313. do 1345., čini se da rješavanje kaznenih predmeta ostaje i dalje u njihovoj nadležnosti, u sklopu Velikoga sudbenog dvora (Curia maior). ${ }^{78}$

O zadarskom sudstvu u ratnim godinama 1345. - 1346. nije poznato gotovo ništa. Zna se da je u vrijeme pobune protiv Venecije u Zadru bilo „stanovitih pokušaja organizacije gradske vlasti na čelu sa trojicom rektora". ${ }^{79}$ Odlaskom mletačkoga kneza iz grada na početku opsade ${ }^{80}$ trojica zadarskih rektora preuzimaju ovlasti gradske vrhovne vlasti, među kojima i ovlaštenje da sude u kaznenim predmetima, ${ }^{81}$ što potvrđuje i prijepis sudskoga zapisnika iz 1346. godine. No funkcija rektora, zajedno s gradskim sudovima, ukida se dolaskom mletačke vlasti u Zadar nakon 21. prosinca 1346., čime sudbenost ponovno prelazi u ruke mletačkoga kneza i savjetnika. ${ }^{82}$ Takva situacija ostaje na snazi sve do dolaska Zadra pod vlast kralja Ludovika I. Anžuvinca 1358. godine. ${ }^{83}$

77 U tom razdoblju, a posebice nakon 1313., Zadrani su često postavljali zahtjeve za određene promje-
ne u upravi i sudstvu u nastojanjima da ograniče mletački utjecaj u komuni. Popić, Krojenje pravde,
61-64. Gradski suci sudjelovali su i u sudbenoj i u izvršnoj vlasti (rješavanje kaznenih predmeta i
građanskih sporova). Popić, „Izvorne cjeline”, 323. O ostalim promjenama u upravi i sudstvu nakon
ugovora o miru s Venecijom 1313. vidi i: Beuc, „Statut zadarske komune”, 515, 517-518; Nada Klaić,
Ivo Petricioli, Zadar u srednjem vijeku do 1409. Prošlost Zadra II (Zadar: FFZd, 1976), 213-215. ${ }_{78}$ U prvoj polovini 14. stoljeća postojala je podjela sudbenih poslova na Veliki (knez i suci) i Mali sudbeni dvor (niži gradski sudovi). Popić, Krojenje pravde, 63. I u Dubrovniku je Veliki sud (Curia maior), zajedno s knezom, bio nadležan za kaznene predmete. Lonza, „'Pred gosparom knezom”, 30.

79 Popić to zaključuje prema postojećem notarskom materijalu za navedene godine u Diplomatičkom zborniku (sv. 11). Vidi: Popić, Krojenje pravde, 66 (bilj. 273). Riječ je o nekoliko notarskih dokumenata nastalih od 17. rujna 1345. do 15. prosinca 1346. koji bilježe različita imena trojice zadarskih rektora, koja su se zapisivala uz ugarsko-hrvatskoga kralja Ludovika i zadarskoga nadbiskupa Nikolu de Matafaris (nakon formule datacije).

80 Mletački knez Marko Corner prebačen je na mletačku galiju sa svojim slugama i namještajem iz Zadra uoči mletačke blokade grada 12. kolovoza 1345. (po zapovijedi glavnoga kapetana deset galija Petra de Canale). Obsidio, knj. 1, pogl. 7, str. 138.

${ }_{81}$ Prema Popiću, središnja vlast (i njezin predstavnik) uvijek je nastojala zadržati pod svojim nadzorom pravo odlučivanja u kaznenim predmetima. Na taj način mogla je nametati sankcije pojedincima u određenim zločinima kako je htjela, s ciljem zadržavanja kontrole i očuvanja postojećega društvenog poretka. Popić, Krojenje pravde, 65.

82 Ulaskom Mlečana u Zadar rektore zamjenjuju dva mletačka kapetana: Andrija Maurocen (Morosini) i Marko Giustiniani. Obsidio, knj. 2, pogl. 19, str. 286. I građanske i kaznene sporove rješavao je mletački knez sa svojim savjetnicima. Popić, Krojenje pravde, 64.

83 Od kraja siječnja 1358. do kraja ožujka 1359. rektori ponovno samostalno upravljaju gradom do izbora novoga kneza. U to vrijeme vodili su i sudske poslove u sklopu Velikoga sudbenog dvora. Nakon ožujka 1359. rektore zamjenjuju knez i suci koje je biralo gradsko Veliko vijeće, što će potrajati do siječnja 1361. godine. Konsolidacijom kraljevske vlasti, odnosno uvođenjem „dvojnosti” vlasti u Zadru dolazi do reformi u organizaciji gradskoga sudstva (odvajanje građanske i kaznene sudbene djelatnosti). Predstavnici izvršne vlasti u Zadru, knez (u pravilu hrvatsko-dalmatinski ban i kraljev 
Postupak ispitivanja optuženika, kako se navodi u prijepisu zapisnika, imao je utvrditi razlog njegova ulaska u Zadar i identitet osobe koja ga je poslala na izvršenje planiranih zadataka. ${ }^{84}$ Ali kako optuženik nije surađivao tijekom ispitivanja, rektori su odredili da ga se podvrgne torturi (... positus fuit ad tormentum.). ${ }^{85}$ Nakon što je odlučio reći istinu prestalo se s primjenom torture (... fuit depositus de tormento...) te mu je određen predah od jednoga sata radi odmora. Nakon stanke optuženik iznosi priznanje u obliku iskaza koji sudski notar oblikuje i upisuje u zapisnik. Na kraju zapisnika bilježi se da rektori postavljaju optuženi$\mathrm{ku}$ dodatna pitanja o planiranim djelovanjima nakon ulaska u grad. ${ }^{86}$ Sudeći po nedovršenom tekstu, moguće je da iskaz nije bio zapisan do kraja, o čemu je već bilo riječi. ${ }^{87}$

Prema opisanom kontekstu, istražni postupak najvjerojatnije je održan u tajnosti, o čemu svjedoči i provedena mjera torture, što je bilo uobičajeno za takav tip inkvizicijskoga postupka. ${ }^{88}$ Kako i stoji u zapisniku, cilj ispitivanja i mučenja optuženika bio je da kaže „čistu istinu” (... puram dicere veritatem...), odnosno obrazloži svoje namjere za koje ga se tereti u optužnici. ${ }^{89} \mathrm{~S}$ obzirom na to da je nakon mučenja optuženik dao iskaz pred sudom, priznanje iznuđeno torturom

predstavnik) i trojica zadarskih rektora iz redova gradskoga plemstva, rješavaju kaznene (i dio građanskih) predmeta unutar Sudbenoga dvora rektora, u sklopu Velikoga sudbenog dvora. Takva organizacija sudstva potrajala je sve do ponovnoga dolaska mletačke vlasti u Zadar 1409. godine. Popić, Krojenje pravde, 66-72.

${ }^{84}$ HR-DAST-156, Obitelj Fanfogna-Garagnin, Spisi 1, Prijepisi, Inquisitio (16. - 17. rujna 1345.), druga stranica.

${ }^{85}$ Ne navodi se koja je metoda mučenja primijenjena u postupku protiv Uguiccionea. Odredbe o torturi zabilježene su u izgubljenom rukopisu zadarskoga statuta iz prve polovine 14. stoljeća (primjerak se čuvao u knjižnici talijanske gimnazije u Zadru, sign. 3209 G. 8). U Brunellijevu prijepisu ostalo je sačuvano dvadesetak tih odredbi zajedno s ostalim propisima. Prema Brunelliju, radi se o važnim odredbama za koje kaže da „illustrano la pratica forense nella Curia criminale zaratina”. Prema jedanaestoj odredbi o torturi, o sucima i njihovim nadležnostima, odnosno diskreciji, ovisilo je kako se primjenjivalo mučenje na optuženika, što pokazuje da se postupak odvijao u tajnosti (Undecima regula est: qualiter et quantum torture imponat, remaneat in arbitrio et discretione iudicis...). Navodi se nekoliko mogućih načina mučenja: ... per funem, vel aquam per nares infundendo, vel per acetum, vel per ungues, vel per tibias, vel cum lapidibus ad pedes. ... qualibet, vel per ignem, vel ad funem sive ad quinelum. Vitaliano Brunelli, „Gli Statuta Jadertina”, Programma dell'I. R. Ginnasio superiore di Zara 49 (1906): 27-28.

${ }^{86}$ HR-DAST-156, Obitelj Fanfogna-Garagnin, Spisi 1, Prijepisi, Inquisitio (16. - 17. rujna 1345.), druga, treća i četvrta stranica.

87 Vidi ovdje str. 137.

${ }^{88}$ Vidi ovdje bilj. 85. Dean, Crime and Justice, 18. Postojala je tajnost postupanja u procesima pokrenutima po službenoj dužnosti. Usp. Tomašević, Krstulović Dragičević, Pleić, „Pravni položaj okrivljenika", 81.

${ }^{89}$ Usp. Vallerani, Medieval Public Justice, 36, 38. Cilj primjene torture nije kazna nego dobivanje istinitoga iskaza. Vidi odredbu o torturi br. 4 (zadarski statut) u: Brunelli, „Gli Statuta Jadertina”, 26. 
smatralo se valjanim dokazom. ${ }^{90}$ Metodi torture kao fizičke prisile najčešće se pristupalo upravo u inkvizicijskim postupcima, posebice za teške zločine (uključujući izdaju, urotu i ostale zločine protiv javne vlasti). Postoji mišljenje da se sudska tortura koristila kao krajnje sredstvo u kaznenom postupku u svrhu dobivanja istinitoga iskaza, ${ }^{11}$ što je bio slučaj i u zadarskom zapisniku. U pojedinim talijanskim gradovima tortura je bila regulirana normativnim okvirom (npr. Bologna, Reggio Emilia, Firenca), ${ }^{92}$ a zabilježena je i u srednjovjekovnim statutima dalmatinskih gradova (Split, Korčula, Brač, Trogir, Zadar). ${ }^{93}$

O sudbini optuženika nakon suđenja svjedoči presuda zabilježena u obliku kratke bilješke na lijevoj margini prijepisa. Sadržaj bilješke otkriva da je optuženik bio osuđen na smrtnu kaznu dekapitacijom (Quod amputetur ei caput de gratia nobilitatis causa). ${ }^{94}$ Iako o izvršenju presude ne postoji potvrda ni u jednom izvo$\mathrm{ru},{ }^{95}$ sasvim je sigurno da je bila provedena s obzirom na težinu zločina. Smrtna kazna dekapitacijom najčešće se dosuđivala za teške zločine (ubojstva, herezu ili zločin protiv vlasti). ${ }^{96}$ Takva vrsta smrtne kazne često se provodila na javnim mjestima (gradski trg), čime je vlast pokazivala svoju moć i autoritet. ${ }^{97}$ Naposljet-

90 Općenito, priznanje u obliku osobnoga iskaza smatralo se nepobitnim dokazom u takvu postupku. Carraway Vitiello, Public Justice, 114-115, 148. Prema ius commune, najviši dokazi u postupku bila su svjedočenja dvaju očevidaca ili priznanje. Ikins Stern, „Public Fame”, 205. O iznudi priznanja u inkvizicijskom procesu pod torturom vidi: Rolandinus Passagerii, Summa artis notariae, pogl. 9, str. 711. O valjanosti priznanja pod torturom vidi: Lonza, „Pred gosparom knezom”, 40, 42.

91 Vidi u: Pennington, „Introduction to the Courts”, 13 (i bilj. 37), 18. Vidi slično i za sudsku torturu u dalmatinskim srednjovjekovnim gradovima: Tomašević, Krstulović Dragičević, Pleić, „Pravni položaj okrivljenika”, 103.

92 Bologna: Blanshei, Politics and Justice, 315, 320-337; Blanshei, Cucini, „Criminal Justice”, 347-348; Dean, Crime and Justice, 18. Reggio Emilia: Carraway Vitiello, Public Justice, 117-118. Firenca: Ikins Stern, „Public Fame”, 209-210, 217.

93 Pojedini statuti dozvoljavali su torturu kao sredstvo prisile, posebno za teške zločine za koje nema svjedoka ili postoje samo javne glasine ( $f a m a)$ kao indicija. Za statut Brača vidi: Tomašević, Krstulović Dragičević, Pleić, „Pravni položaj okrivljenika”, 104. Općenito o torturi u statutima dalmatinskih gradova vidi: Tomašević, Krstulović Dragičević, Pleić, „Pravni položaj okrivljenika”, 88, 92, 100, 103-106. Odredbe o torturi u spomenutom rukopisu zadarskoga statuta: Brunelli, „Gli Statuta Jadertina”, 25-35; Beuc, „Statut zadarske komune”, 495. Prema Lonzi, metoda torture nije uvijek bila regulirana propisima. Iako ta odredba nije zapisana u dubrovačkom statutu (1272.), tortura se ipak primjenjivala u sudskoj praksi te se bilježila u kasnijim zakonskim propisima. Lonza, „Pred gosparom knezom"', 42 (i bilj. 160 i 161).

94 Vidi ovdje bilj. 17.

95 Autor Obsidio Iadrensis ne bilježi nikakve podatke nakon uhićenja Toskanca. Obsidio, knj. 2, pogl. 17, str. 272.

96 Dekapitacija se dosuđivala i za optuženike u bijegu koji bi bili uhićeni nakon povratka u grad (tzv. banniti). Vidi: Carraway Vitiello, Public Justice, 163, 173; Sarah Rubin Blanshei, „Criminal Justice in Medieval Perugia and Bologna”, Law and History Review 1 (1983), br. 2: 258, 260-262; Dean, Crime and Justice, 36, 164; Zorzi, „The judicial system in Florence”, 54; Blanshei, Politics and Justice, 332, 486.

${ }_{97}$ Usp. Carraway Vitiello, Public Justice, 173. O javnom pogubljenju (dekapitaciji) grupe urotnika na gradskom trgu u Pisi (1356.) vidi: Dean, Crime and Justice, 64. 
ku, izvršenje takve kazne na javnome mjestu trebalo je poslužiti i kao primjer ostalim građanima.

Slični primjeri o javnim smaknućima (dekapitaciji) ostali su zabilježeni i u zadarskim srednjovjekovnim narativnim izvorima. Prema njima, dekapitacijom su se kažnjavali urotnici i izdajice u Zadru u 14. i početkom 15. stoljeća. Obsidio Iadrensis bilježi javno smaknuće dvojice plemića, Bivalda i njegova sina Grgura de Botono, i dvojice pučana koji su sudjelovali u pobuni pučana protiv gradskih vlasti u vrijeme opsade Zadra. Smrtna kazna dekapitacijom izvršena je na glavnom gradskom trgu 25 . srpnja 1346 . godine. ${ }^{98}$ Slične primjere u kojima se pučane optužuje za izdaju komune i nasilje protiv plemstva bilježi i zadarski kroničar i rektor Pavao Pavlović krajem 14. i početkom 15. stoljeća. ${ }^{99}$ Pavlović bilježi dva slučaja urote u kojima su sudionici bili kažnjeni dekapitacijom na glavnom gradskom trgu. Prvi se odnosi na urotnike suknara Zanina, njegova rođaka Dankarola, Petra Franchalancu i Mišula Milešića, koji su pogubljeni zbog izdaje 11. srpnja 1384. godine. ${ }^{100} \mathrm{U}$ drugom zapisu Pavlović bilježi dekapitaciju urotnika, krojača Andrije, na glavnom gradskom trgu 6. prosinca 1401. godine. Prema optužbi, Andrija se udružio s Angelom Nikolinim, podstrigačem sukna, i još nekim strancima (forensibus) radi ubijanja nekih zadarskih plemića. ${ }^{101}$ Ono što je također zajedničko tim primjerima aktivna je uloga komune u raspolaganju njihovom imovinom. Zadarska komuna plijeni imovinu urotnika/izdajica, koju zatim ili stavlja na javne dražbe (zbog isplate vjerovnika) ili daje na podjelu unutar njihovih obitelji, što je potvrđeno i u notarskim dokumentima toga vremena. ${ }^{102}$

${ }_{98}$ Zbog optužbi za urotu protiv zadarske komune i suradnju s mletačkim neprijateljima uhićeno je i kažnjeno jedanaest pučana zajedno s navedenim plemićima. Smrtnu presudu dobila su samo četvorica, najvjerojatnije zbog toga što ih se smatralo vođama urote. Četvorica pučana dobila su tjelesnu kaznu (osljepljivanje), a preostali doživotni zatvor. Vidi: Obsidio, knj. 2, pogl. 12, str. 254-258.

99 Pavlović bilježi te primjere u svojem ljetopisu Memoriale Pauli de Paulo patritii iadrensis (13711408). Tekst je objavio i uredio Ferdo Šišić u: „Ljetopis Pavla Pavlovića patricija zadarskoga”, Vjestnik Kr. hrvatsko-slavonsko-dalmatinskog zemaljskog arkiva 6 (1904): 1-59.

${ }^{100}$ Pavlović ne bilježi razloge te „izdaje”. Navodi da su 11. istoga mjeseca (srpnja) oko trećega sata urotnici bili vučeni po gradu te im je odrubljena glava na glavnom gradskom trgu. Tijela su im nakon dekapitacije ostala ležati na trgu cijeli dan sve do večeri. Šišić, „Ljetopis”, 8.

101 Šišić, „Ljetopis”, 33.

${ }^{102}$ Za Bivalda de Botono vidi njegov inventar dobara, sastavljen dva tjedna nakon njegova smaknuća (8. 8. 1346.), u: MCI 1, dok. 10, str. 85-105. U slučaju protiv Zanina, Dankarola, Petra Franchalance i Mišula Milešića, tjedan dana nakon njihova smaknuća sastali su se njihovi vjerovnici s trojicom zadarskih sudaca da bi se prodala njihova imovina i tako isplatila dugovanja. Šišić, „Ljetopis”, 8. O pljenidbi i podjeli imovine Milešića i isplati njegovih vjerovnika vidi: HR - Državni arhiv u Zadru, Zadar (dalje: DAZD) - fond 31 - Bilježnici Zadra (dalje: BZ), Raymundus de Modiis (dalje: RM), b. 1, fasc. 1, 37v-38v i b. 1, fasc. 1, 40 (1385.). O zapljeni i prodaji kuće suknara Zanina na javnoj dražbi vidi: HR-DAZD-31-BZ, Articutius de Rivignano (dalje: AR), b. 1, fasc. 1, fol. 99-99v (29. 8. 1384.). Što se tiče njegova rođaka Dankarola, čini se da mu je to bio nadimak. Pravo mu je ime bilo Nikola, sin Grgura. O prodaji njegovih izvangradskih nekretnina na javnoj dražbi vidi: HR-DAZD-31-BZ, AR, b. 1, fasc. 1, 139v-140 (6. 11. 1384.). Tjedan dana poslije prodaje se na javnoj dražbi još jedno njegovo 
Zanimljiv je i podatak da se u tim notarskim dokumentima većinu urotnika pučana bilježi kao „nevjernike ugarske krune i komune, buntovnike i izdajice”, ${ }^{103}$ a slična klasifikacija izostaje za plemiće poput Bivalda i Grgura de Botono. ${ }^{104}$ Iako razlog ostaje nepoznat, odgovor se krije u tadašnjim sukobima između pučana i plemstva, koje je bilo nositelj vlasti u zadarskoj komuni. ${ }^{105} \mathrm{U}$ skladu s tim, svakako bi bilo korisno istražiti pravni položaj tih dviju društvenih skupina unutar tadašnjega kaznenopravnog okvira, ali, nažalost, za to nedostaju ključni izvori (statutarne odredbe, registri kaznenih predmeta, kapitulari), kao i studije u postojećoj historiografiji.

Slično postupanje zadarskih rektora vezano za provedbu inkvizicijskoga postupka i izvršenje presude u vrijeme mletačke opsade Zadra bilježi i autor Obsidio Iadrensis. Osim što funkciju rektora u to vrijeme bilježi notarski materijal, ${ }^{106}$ zapise o njima navodi i spomenuti autor. ${ }^{107}$ Iako se u Obsidio ne bilježe imena rektora, opisuju se njihove aktivnosti u vođenju grada u vrijeme opsade. ${ }^{108}$ Jedan od takvih važnijih opisa odnosi se na njihovu ulogu u procesu uhićenja i suđenja urotnicima koji su sudjelovali u spomenutoj pobuni pučana u srpnju 1346. godine. Autor bilježi da su petoricu urotnika neki građani doveli pred rektore te da su urotnici „bez upotrebe ikakvih mučila” dali priznanje u kojem su otkrili iden-

zemljište koje se nalazilo na otoku Tkonu: HR-DAZD-31-BZ, AR, b. 1, fasc. 1, 142v-143. O imovini Petra Franchalance i krojača Andrije iz 1401. nisu zasad pronađeni slični podaci.

${ }^{103}$ Mišul Milešić naziva se u dokumentima ... rebelis predictionis comunis Jadre prope delictum..., ... proditoris et infidelis... HR-DAZD-31-BZ, RM, b. 1, fasc. 1, 37v, 40 (1385.). Zanina se naziva ... infidelis sacre regie maiestatis Ungarie et comunis Jadre sac proditoris... HR-DAZD-31-BZ, AR, b. 1, fasc. 1, fol. 99 (1384.). Nikolu (Dankarola) bilježilo se nevjernikom krune i zadarske komune (... infidelis...) te izdajicom domovine (... proditoris patrie...). Vidi: HR-DAZD-31-BZ, AR, b. 1, fasc. 1, 139v, 142v-143 (1384.).

${ }^{104}$ Primjerice, u inventaru Bivalda ne postoji takva klasifikacija. Prema postojećim istraživanjima, čini se i da njihov čin „izdaje” nije imao velik utjecaj na daljnji razvoj njihove obiteljske grane. Vidi: Sandra Begonja, Zrinka Nikolić Jakus, „The Noble Families of Butovan and Botono in Medieval Zadar: Family Structure, Property Reconstruction, and Social Life", Povijesni prilozi 38 (2019), br. 56: 94.

${ }^{105} \mathrm{U}$ to vrijeme gradsku vlast obnašaju pripadnici gradskoga plemstva, koji vode unutarnju i vanjsku politiku komune te često dolaze u sukob s pučanima, kako to uostalom pokazuju i primjeri pobune pučana u vrijeme opsade grada, a i kasniji primjeri kod Pavlovića. U djelu Obsidio Iadrensis izrazito je naglašen negativan stav samoga autora prema pučanima (naziva ih „izdajicama domovine”). Osim što upućuje na autorovo plemenito podrijetlo, taj stav odražava i animozitet između tih dviju društvenih skupina. Obsidio, knj. 2, pogl. 11 i 12, str. 250-258. O pobuni opisanoj u Obsidio, kao i mišljenje Nade Klaić o tadašnjim odnosima pučana i plemstva, vidi u: Klaić, Petricioli, Zadar, 242-246.

106 Vidi ovdje bilj. 79. Vidi i zapise o zadarskim rektorima u inventarima zadarskih građana za 1346. (od 25. ožujka do 11. studenog): MCI 1, dok. 7, str. 55, dok. 8, str. 66, dok. 9, str. 82, dok. 10, str. 86, dok. 11, str. 106, dok. 12, str. 136.

${ }^{107}$ Osim trojice rektora bilježi se i 12 zadarskih predstavnika „o kojima je ovisio čitav grad” (Malo vijeće) te sveopće vijeće od 200 vijećnika u općinskoj dvorani (Glavno ili Veliko vijeće). Obsidio, knj. 2, pogl. 7, str. 232, pogl. 11, str. 252, pogl. 18, str. 280. I kralj Ludovik I. Anžuvinac obraća se rektorima i vijeću u svojim pismima. Obsidio, knj. 2, pogl. 2, str. 206, 208.

${ }^{108}$ Obsidio, knj. 1, pogl. 11, str. 154; knj. 2, pogl. 7, str. 232. 
titet ostalih sudionika pobune. Jedanaestoricu pučana i dvojicu plemića, Bivalda i sina Grgura de Botono, odvojeno su stavili u zatvor ${ }^{109}$ (do izvršenja presude). ${ }^{110}$ Iako se proces suđenja ne spominje izravno u tekstu, opis upućuje na provedbu inkvizicijskoga postupka, slično kako je zabilježen i u zapisniku iz 1346. godine. Međutim, za razliku od zapisnika, u tom opisu postoji vremenski okvir od uhićenja do izvršenja presude. ${ }^{111}$ Cijeli postupak trajao je otprilike dva dana gledajući od dana uhićenja (23. srpnja) do dana izvršenja presude (25. srpnja). S obzirom na te podatke, vrlo je vjerojatno da je i inkvizicijski postupak opisan u prijepisu zapisnika imao slično vrijeme trajanja, odnosno suđenje je obavljeno relativno brzo i u tajnosti. ${ }^{112}$ Sličan primjer zabilježen je u Obsidio Iadrensis i nekoliko mjeseci prije, točnije krajem siječnja 1346. godine. Ubrzo nakon postupka torture i priznanja izdajice su bili obješeni na gradskim kulama. ${ }^{113}$ Čini se da je takva brzina kaznenoga postupanja (u slučajevima urote i izdaje) ostala i u drugoj polovini 14. stoljeća. ${ }^{114}$

Zadarska komuna najoštrije je kažnjavala svaku moguću urotu ili izdaju, kako je opisano u navedenim primjerima iz 14. te početka 15 . stoljeća. O sustavu kažnjavanja urotnika/izdajica u prijašnjim razdobljima zasad nema podataka. ${ }^{115} \mathrm{Među}$ tim, čini se da upravo u vrijeme jače konsolidacije vlasti, odnosno razvoja i jačanja komunalnih institucija, dolazi i do izraženije primjene službenoga progona, sudske torture i rigoroznijega kaznenog sustava za zločine koji su ugrožavali mir, stabilnost i pravni poredak komune, što potvrđuju i slična europska iskustva. ${ }^{116}$

\section{Vojno-politički aspekt}

Prijepis zapisnika sadržava važne podatke koji donose nove spoznaje o vojno-političkom aspektu događanja u posljednjoj fazi mletačke opsade Zadra 1346. go-

\footnotetext{
${ }^{109}$ Obsidio, knj. 2, pogl. 12, str. 254, 256.

${ }^{110}$ Vidi ovdje bilj. 98.

${ }^{111}$ U sudskom zapisniku iz 1346. ne bilježe se podaci o Uguiccioneu nakon davanja iskaza.

112 Vidi ovdje str. 145.

${ }^{113}$ Nekolicina izdajica namjeravala je predati Mlečanima neke zadarske kule tijekom bitke za gradski lanac 23. siječnja 1346. godine. Njih su prijavili „predsjedateljima uprave grada” (rektorima) isti ljudi koji su s njima sudjelovali u planiranju tih aktivnosti. Pogubljeni su ubrzo nakon uhićenja, u razmaku od nekoliko dana. Obsidio, knj. 1, pogl. 23, str. 192, 196, 198, 200.

${ }_{114}$ Prema Pavlovićevu zapisu, izdaja (proditio) koju su htjeli učiniti suknar Zanin, njegov rođak Dankarol, Petar Franchalanca i Mišul Milešić otkrivena je 8. srpnja, a oni su pogubljeni 11. srpnja 1384. godine. Vidi: Šišić, „Ljetopis”, 8.

115 Tijekom ovoga istraživanja nisu pronađeni slični primjeri za 13. i prvu polovicu 14. stoljeća (do 1340-ih).

116 Tijekom 13. i 14. stoljeća s razvojem komunalnih institucija i općenito društva primjetno jača mehanizam moći i kontrola javne vlasti. Glavni pokazatelji odnose se na češću primjenu inkvizicijskoga postupka (uz torturu) i rigorozniji režim kaznenoga sustava, posebno za teške zločine (od 1350-ih). Lonza, „Tužba, osveta, nagodba”, 76-77, 101; Blanshei, „Criminal Justice”, 261, 264.
} 
dine. ${ }^{117}$ Ti se podaci odnose uglavnom na topografiju, vojnu terminologiju (titulacije, arhitektura) i osobe zapisane u kontekstu događanja opisanih u tekstu. $\mathrm{Na}$ temelju tih saznanja, uz dopunu sličnim podacima iz ostalih izvora, nastala je vremenska i prostorna rekonstrukcija događanja opisanih u prijepisu sudskoga zapisnika. U skladu s tim, došlo se i do određenih spoznaja o planiranim metodama, subjektima i cilju izvršenja glavnoga zadatka. Pritom je utvrđena i uloga visokih mletačkih vojnih dužnosnika i stranih plaćenika u planiranju i izvedbi određenih ratnih djelovanja. Sadržaj zapisnika donosi i važan uvid u ulogu stranih plaćenika i u mletačkoj i u zadarskoj vojsci, što ujedno proširuje postojeća znanja o ulozi plaćenika u europskom srednjovjekovlju.

Događaji zabilježeni u prijepisu zapisnika odnose se na treću fazu mletačkih vojnih operacija u opsadi Zadra (srpanj - studeni 1346.). ${ }^{118}$ Posljednja faza ratnih događanja započinje odlaskom kralja Ludovika I. Anžuvinca i njegove vojske iz zadarskoga zaleđa nakon poraza u bitci za mletačku bastidu 1. srpnja 1346. godine. ${ }^{119}$ Tijekom toga razdoblja Mlečani pregrupiraju vojsku i jačaju pritisak na grad, želeći što prije okončati opsadu u koju su uložili mnogo novca, ljudstva i opreme. Osim vojnim sredstvima, cilj nastoje postići i politikom aktivnoga podmićivanja pojedinih skupina (zadarski pučani, vojnici), kojom naposljetku i uspijevaju osvojiti posljednje izvangradsko uporište zadarskih snaga, utvrdu sv. Mihovila (10. kolovoza). Pojedinačnim akcijama protiv Mlečana u okolici Zadra

${ }^{117}$ Mletačka opsada Zadra (1345./1346.) rezultat je višegodišnjega nastojanja Zadrana da se oslobode mletačke vlasti, posebice nakon posljednjega zadarsko-mletačkog rata 1313. godine. Dolazak kralja Ludovika Anžuvinca u zaleđe dalmatinskih gradova 1344./1345. Zadrani vide kao priliku da se oslobode mletačke vlasti i stave pod zaštitu Anžuvinaca. Reakcija Venecije na ugrožavanje njihove vlasti nad Zadrom bila je brza i promišljena - Mlečani šalju veliku kopnenu i pomorsku vojsku na Zadar i drže grad u blokadi zahtijevajući bezuvjetnu predaju. Opsada je trajala od 12. kolovoza 1345. do 21. prosinca 1346., kad Zadrani ponovno dolaze pod vlast Venecije. Tijekom toga razdoblja Zadrani uz pomoć kralja i ugarsko-hrvatske vojske pružaju žestoki vojni otpor Veneciji, što je rezultiralo višemjesečnim borbama i mletačkim pokušajima osvajanja grada. O sveukupnim događanjima uoči, tijekom i neposredno nakon opsade, kako ih opisuje autor Obsidio Iadrensis, vidi: Obsidio, 114-291. O političkim prilikama uoči i tijekom opsade Zadra te izvoru Obsidio Iadrensis vidi: Kurelac, Karbić, „Uvod - Ljetopis”, 3-20. Kronologiju događanja prema različitim izvorima od lipnja 1344. do sredine svibnja 1347. vidi u: Damir Karbić, Zoran Ladić, „Uvod - Kronologija događaja”, u: Obsidio Iadrensis = Opsada Zadra, Monumenta spectantia historiam Slavorum Meridionalium 54, Scriptores VI, ur. Branimir Glavičić et al. (Zagreb: HAZU, 2007), 21-35. Pregled postojeće historiografije i izvora za mletačku opsadu Zadra vidi u: Sandra Begonja, „Srednjovjekovno djelo Obsidio Iadrensis / Opsada Zadra kao povijesni izvor za prikaz vojnopomorske moći Venecije u 14. stoljeću", Povijesni prilozi 33 (2014), br. 47: 81-84. O vojno-političkom aspektu događanja u vrijeme opsade vidi: Begonja, „Srednjovjekovno djelo", 84-141.

${ }^{118}$ Begonja, „Srednjovjekovno djelo”, 105.

${ }^{119}$ Kralj Ludovik dolazi sa svojom vojskom pred mletačku bastidu oko 15. lipnja 1346. godine. Otad pa sve do velike bitke 1. srpnja trajale su opsadne radnje i manji sukobi između Mlečana te kralja Ludovika i Zadrana. Nakon poraza na bastidi 1. srpnja Ludovik se povlači prema Vrani (3. srpnja). Obsidio, knj. 2, pogl. 7-9, str. 230-244. Analizu vidi u: Begonja, „Srednjovjekovno djelo”, 104-105. 
Zadrani nastoje razbiti obruč i oslabiti pritisak na grad, što se nastavlja i tijekom listopada 1346. godine. ${ }^{120}$

Prema iskazu optuženika ${ }^{121}$ moguće je pratiti vrijeme i mjesto njegova kretanja od Vicenze do Zadra, kao i kontakte s kojima je ugovarao buduće zadatke. Poštujući formu zapisnika, sudski notar na pojedinim mjestima u tekstu oblikuje dijelove iskaza u upravnom govoru, posebno prilikom iznošenja mišljenja mletačkih dužnosnika koje navodi optuženik.

Iskaz započinje iznošenjem događaja koji su uslijedili nakon odlaska Uguiccionea iz Vicenze. Uguiccione odlazi s preporukom Marka Dandula, potestata Vicenze, u posjet dogovorenome mletačkom kontaktu u Veneciji, Marku Superantiju. Kao datum njegova odlaska iz grada navodi se završetak svetkovine u Vicenzi. Iako u prijepisu zapisnika nedostaje cjelovit naziv toga blagdana (... post festum Sancti Be... ... de Vincentia...) ${ }^{122}$ najvjerojatnije je riječ o svetkovini pod nazivom Beatorum Martyrum S. Felicis et Fortunati confessorum et martyrum Dei, čije su se relikvije nalazile u Vicenzi. ${ }^{123}$ Točan datum proslave toga blagdana ostaje i dalje sporan, ${ }^{124}$ no svetkovina je održana najvjerojatnije negdje nakon Uskrsa (moguće i u rano ljeto) 1346. godine.

Marko Dandulo, njegov glavni posrednik u povezivanju s mletačkim dužnosnicima, obnašao je funkciju potestata Vicenze ${ }^{125} 1344$. - 1346., moguće čak i 1348. godine. ${ }^{126}$ Dandulo je aktivno sudjelovao u mletačkim poslovima u Hrvatskoj

\footnotetext{
${ }^{120}$ Begonja, „Srednjovjekovno djelo”, 106-107.

${ }^{121}$ HR-DAST-156, Obitelj Fanfogna-Garagnin, Spisi 1, Prijepisi, Inquisitio (16.-17. rujna 1345.), druga, treća i četvrta stranica.
}

${ }^{122}$ HR-DAST-156, Obitelj Fanfogna-Garagnin, Spisi 1, Prijepisi, Inquisitio (16. - 17. rujna 1345.), druga stranica.

${ }^{123}$ Kult tih svetaca dijelile su i Vicenza i Akvileja. Vidi detaljnije: Alan Thacker, „Popes, Patriarchs and Archbishops and the Origins of the Cult of the Martyrs in Northern Italy", u: Saints and Sanctity. Studies in Church History, sv. 47, ur. Peter Clarke i Tony Claydon (Woodbridge: Boydell \& Brewer, 2011), 66-69.

${ }^{124}$ U Milanu i Akvileji bilježe se različiti datumi održavanja te svetkovine (14. svibnja, 14. kolovoza). Thacker, „Popes, Patriarchs and Archbishops”, 66-69. Prema Mironiju, čini se da se nekoć i u Vicenzi taj blagdan slavio 14. kolovoza. Međutim, zbog neprikladnoga datuma održavanja svetkovine komunalna vlast Vicenze donosi dekret o njegovoj proslavi prvoga dana nakon Uskrsa (uvršteno i u gradski statut od 1311.). Prema navedenom, blagdan se slavio nakon Uskrsa, vjerojatno negdje u travnju. No zasad ostaje nepoznato je li se to i provodilo u praksi. Vidi: Francesco Barbarano de Mironi da Vicenza, Historia ecclesiastica della città, territorio e diocese di Vicenza (Vicenza: Rosio, 1649), 84. Odredbu vidi i u: Ius civile vincentinum (Venezia: Francesco Bindoni i Maffeo Pasini, 1539), knj. statuta br. 4, 119.

125 ... ex parte domini Marci Danduli, potestatis Vincentie... HR-DAST-156, Obitelj Fanfogna-Garagnin, Spisi 1, Prijepisi, Inquisitio (16. - 17. rujna 1345.), druga stranica.

${ }^{126}$ Prema: Battista Pagliarino, Croniche di Vicenza, knj. 1 (Vicenza: Appresso Giacomo Amadio, stampator della citta, 1663), 110, 114: „Del 1346. Marco Dandolo Venetiano Podestà di Vicenza, \& Betugio da Reggio suo Vicario” i „Del 1348. Marco Dandolo Venetiano Podestà di Vicenza”. Castellini bilježi Marka Dandola kao potestata Vicenze 1344. - 1346., ali ne i 1348. godine. „(1344.) Fu Podestà 
i Dalmaciji uoči opsadnih događanja $1345 .{ }^{127}$ što pokazuje da je bio upoznat s tadašnjim planovima i aktivnostima mletačkih vlasti vezano za događanja $\mathrm{u} \mathrm{Za}$ dru. Izravni kontakt s potestatom kao najvišim predstavnikom komunalne vlasti u Vicenzi govori da je Uguiccione bio blizak tadašnjim visokim političkim krugovima te da nije bio običan vojni plaćenik (stipendarius), što se uostalom nigdje i ne navodi u prijepisu zapisnika.

Preporuka Marka Dandula bila je namijenjena Marku Superantiju u Veneciji, s kojim se Uguiccione susreo pri dolasku. Iako Uguiccione u iskazu ne iznosi sadržaj preporuke, može se zaključiti (prema Markovoj reakciji) da je sastavljena s ciljem njegova zapošljavanja u mletačkoj službi. U njegovo ime Marko Superantio dogovara susret s novim pomorskim zapovjednikom, Andrijom Maurocenom. ${ }^{128}$

Iako se u prijepisu zapisnika ne bilježi tadašnja titula ili pozicija Marka Superantija u Veneciji, uočljiva je njegova povezanost s Andrijom Maurocenom, koju potvrđuje i Zadarska kronika, drugi narativni izvor o opsadi Zadra 1345. - 1346. godine. ${ }^{129}$ Naime, u tom djelu bilježi se Marko Superantio (Soranzo) kao jedan

di Vicenza Marco Dandolo Veneziano”, „(1345.) Lo stesso Dandolo fu Podestà”, „(1346.) Essendo ancora Marco Dandolo Podestà di Vicenza...”. Silvestro Castellini, Storia della città di Vicenza, sv. 11 (Vicenza: Tipografia Parise Edit, 1821), 70-71.

${ }^{127}$ Marko Dandulo bio je 1344./1345. dio tročlanoga odbora zaduženog za pojedina pitanja u Zadru, Pagu i Krku. Sudjelovao je i u rješavanju sukoba između paškoga kneza i zadarskoga plemića Vučine de Matafaris zbog ceste i solana na Pagu. Marko Dandulo kao "Savi sopra i conflitti in Zara e Pago" (6. 11. 1344.), u: Benjamin G. Kohl, Andrea Mozzato, Monique O'Connell, ur., „The Rulers of Venice, 1332-1524. Interpretations, Methods, Database" (online baza podataka), pristup ostvaren 24. 10. 2020., http://rulersofvenice.org/main, zapis br. 57087 (Senato misti, reg. 22, fol. 55v). Vidi i: Šime Ljubić, ur., Listine o odnošajih izmedju južnoga Slavenstva i Mletačke Republike, knj. II: Od godine 1336. do 1347., Monumenta spectantia historiam Slavorum meridionalium, sv. 2 (dalje: Listine 2) (Zagreb: JAZU, 1870), dok. CCCLXXXI, str. 227; odluka mletačkih vlasti u rješavanju spora između paškoga kneza, zadarskoga plemića Vučine de Matafaris i Pažana (17. 1. 1344.), u: Maria Francesca Tiepolo, Dieter Girgensohn, Gherardo Ortalli, ur., Venezia - Senato. Deliberazioni miste. Registro XXII (1344-1345), sv. 9 (dalje: DM 22) (Venezia: Istituto Veneto di Scienze, Lettere ed Arti, 2007), str. 260-261 (537-538), 70r, 70v i str. 294 (604), 79v. Vidi i: Listine 2, dok. CCCLXXXIX, str. 231-232; Dandulo u odboru za poslove s Krkom i rasprave između Zadra i Paga u: Listine 2, dok. CCCLXXXI i CCCLXXXII, str. 227228 (6. - 11. 11. 1344.); u odluci o prikupljanju oružja i ljudstva u Hrvatskoj (pred zadarsku opsadu) u: Listine 2, dok. CCCXCVI, str. 237 (3. 3. 1345.). Posljednji put bilježi se pred opsadu Zadra 5. travnja 1345. godine: Listine 2, dok. CCCCII, str. 241.

${ }^{128}$ HR-DAST-156, Obitelj Fanfogna-Garagnin, Spisi 1, Prijepisi, Inquisitio (16. - 17. rujna 1345.), druga stranica.

${ }^{129}$ Osim Obsidio Iadrensis postoji i djelo nepoznatoga autora koji bilježi događaje u opsadi Zadra s promletačke pozicije (Zadarska kronika ili Cronica Jadertina / Chronaca Jadratina). Djelo je sačuvano u prijepisu iz 15. stoljeća, a nalazi se u Marciani. Kurelac, Karbić, „Uvod - Ljetopis”, 14 (bilj. 57), 20; Dolores Butić, „Analiza djela Obsidio Iadrensis - od teksta do autora” (doktorska disertacija, Sveučilište u Zagrebu, 2021), 3. Sačuvani tekst iz Marciane objavili su: Gherardo Ortalli, Ornella Pittarello, ur., Cronica Jadretina. Venezia - Zara, 1345-1346 (Venezia: Istituto Veneto di Scienze, Lettere ed Arti, 2014). Djelo je na talijanskom jeziku objavio Morelli 1673. godine. Jacopo Morelli, ur., Istoria dell'assedio e della ricupera di Zara fatta da Veneziani nell'anno MCCCXLVI scritta da autore contemporaneo. Monumenti veneziani di varia litteratura (Venezia, 1796). 
od dvojice novoizabranih konjaničkih zapovjednika u mletačkoj vojsci pod Zadrom. Njihov izbor dolazi upravo u vrijeme kad Andrija Maurocen obavlja svoju novu dužnost pomorskoga zapovjednika u opsadi Zadra. ${ }^{130}$ Taj podatak pokazuje da je Marko Superantio možda već bio u njegovoj službi u vrijeme Uguiccioneova dolaska u Veneciju. Marka Superantija (Soranza) Obsidio Iadrensis uopće ne bilježi, a ostali ga izvori bilježe u kasnijim dokumentima, kad je obavljao različite vojne i upravne službe (miles, supracomitus, potestat/kapetan Kopra). ${ }^{131}$

Dobivši daljnje upute o postupanju od Marka Superantija, Uguiccione odlazi na galiju Andriola Zena, koja ga prevozi do glavne galije zapovjednika Andrije Maurocena. ${ }^{132}$ Iako se ne bilježi njegova titula, Andriol je najvjerojatnije bio zapovjednik jedne od galija (supracomitus) ${ }^{133}$ koje su se tada nalazile pod zapovjedništvom glavne galije pomorskoga zapovjednika. Riječ je o istoj osobi koja je imenovana novim zapovjednikom utvrde sv. Mihovila 21. kolovoza 1346., ${ }^{134}$ što bi značilo da on, kao i Marko Superantio, putuje zajedno s Andrijom Maurocenom za Zadar, gdje preuzima novu dužnost.

${ }^{130}$ U Zadarskoj kronici bilježi se podatak o pogibiji dvojice mletačkih konjaničkih zapovjednika u manjem sukobu uoči velike bitke za bastidu 1. srpnja 1346. godine. U Morellijevu prijevodu bilježe se Marko Tiepolo i Bonifacije de'Boiardi de Reggio (... due valorosi Contestabili di cavalleria...) kao i u Cronica (... contestabiles equites, videlicet Marcus dictus Theupulo et Bonifatius de Boiardis de Regio...). Morelli, Istoria, XXIV i Ortalli, Pittarello, Cronica Jadretina, 108. Tu vijest potvrđuje buduće imenovanje dvojice novih konjaničkih zapovjednika umjesto dotadašnjih gubernatorum, čija se imena ne navode u dokumentu Vijeća umoljenih. Listine 2, dok. DXCIII, str. 367 (31. 7. 1346.). Iako obje verzije Zadarske kronike bilježe Marka Superantija (Soranza) kao jednoga od tih konjaničkih zapovjednika, navode različite osobe na mjestu drugoga zapovjednika. U Morellijevu prijevodu bilježi se Marko Dolfino, a u Cronica Jakob Dolphino. Vidi: Morelli, Istoria, XXXIV i Ortalli, Pittarello, Cronica Jadretina, 124.

${ }^{131}$ Baillus Negroponta i potestat Asille (districtus Tarvisini) 1344. - 1346., u: Kohl, Mozzato, O’Connell, „The Rulers”, zapis br. 51421; Kenneth Meyer Setton, The Papacy and the Levant, 1204-1571, sv. 1 (Philadelphia: American Philosophical Society, 1976), 454; DM 22, 32-33 (zapis. br. 48), 96-97 (zapis br. 186), 25v (svibanj 1344.). Potvrđen kao vrhovni kapetan u Istri (capitaneus pasynaticus) 19. srpnja 1348. i mletački knez u Dubrovniku na odlasku 1358., u: Šime Ljubić, ur. Listine o odnošajih izmedju južnoga Slavenstva i Mletačke Republike, knj. III: Od godine 1347. do 1358., Monumenta spectantia historiam Slavorum meridionalium, sv. 3 (Zagreb: JAZU, 1872), dok. CXXXVII, 91; Vjekoslav Klaić, Povjest Hrvata. Od najstarijih vremena do svršetka XIX. stoljeća, sv. 2, dio prvi: Treće doba: vladanje kraljeva iz raznih porodica (1301-1526) (Zagreb: Tisak i naklada knjižare Lav. Hartmana /Kugli i Deutsch/, 1900), 130. Više o njemu vidi u: Daniele Dibello, „Marco Soranzo”, Dizionario Biografico degli Italiani, sv. 93, pristup ostvaren 26. 10. 2020., http://www.treccani.it/enciclopedia/marco-soranzo_\%28Dizionario-Biografico\%29/.

${ }^{132}$ HR-DAST-156, Obitelj Fanfogna-Garagnin, Spisi 1, Prijepisi, Inquisitio (16. - 17. rujna 1345.), druga stranica.

${ }^{133}$ Usp. Begonja, „Srednjovjekovno djelo”, 92 (bilj. 67), 93 (bilj. 77), 100 (bilj. 131).

${ }^{134}$ Mlečani dolaze u posjed utvrde 10. kolovoza 1346., vidi ovdje str. 150. Electus capitaneus castri sancti Michaelis ser Andreolus Zane sancti Luce... Listine 2, dok. DCV, str. 376; Klaić, Povjest Hrvata, 130. 
Po dolasku na glavnu galiju, koja se tada nalazila u Zaljevu (Quarnario), ${ }^{135}$ Uguiccione dogovara buduću suradnju sa zapovjednikom Andrijom Maurocenom. Andrija se u prijepisu zapisnika bilježi kao novi zapovjednik svih galija, ${ }^{136}$ odnosno novi pomorski zapovjednik u opsadi Zadra. Taj podatak potvrđuju i Obsidio Iadrensis i mletački izvori koji ga bilježe posljednjim imenovanim vrhovnim zapovjednikom svih galija (i pomorske vojske) u opsadi Zadra (capitaneus gallearum / capitaneus generalis / capitaneus maris). Andrija Maurocen obavljao je tu funkciju od 13. kolovoza 1346. do 20. siječnja 1347. godine. ${ }^{137}$

Andrija Maurocen daje Uguiccioneu na izvršenje glavni zadatak i određuje visinu novčane naknade (udio u 50.000 zlatnih dukata), čime ga Uguiccione u iskazu obilježava kao glavnoga nalogodavca. ${ }^{138}$ Radi se o istome novčanom iznosu koji su mletačke vlasti namijenile za tajne dogovore između svojih vojnih zapovjednika pod Zadrom i pojedinaca koji bi im pomogli u osvajanju grada. Mletački zapovjednici imali su potpunu slobodu u vođenju tih pregovora i dogovaranju radnji potrebnih za izvršenje glavnoga cilja. Datumi dvaju službenih mletačkih dokumenata u kojima se bilježi taj iznos pokazuju namjeru mletačkih vlasti da što prije završe opsadu Zadra. ${ }^{139}$ Međutim, prijepis zapisnika potvrđuje neuspjeh dotadašnjih mletačkih zapovjednika u realizaciji planova, uključujući i dogovoreni tajni plan s Uguiccioneom, kojemu je ponuđen isti novčani iznos za izvršenje istoga cilja.

Čini se da je glavni Maurocenov plan bio da se Uguiccione ubaci u Zadar, gdje su se nalazili njegovi toskanski zemljaci koje je trebao pridobiti na mletačku stranu radi preuzimanja grada. ${ }^{140}$ Maurocen je bio dobro upoznat s mletačkom politi-

${ }_{135}$ Prema Laneu, termin se najvjerojatnije odnosi na zaljev Venecije (linija od Pule prema Ravenni).
Frederic C. Lane, Venice. A Maritime Republic (Baltimore: The Johns Hopkins University Press, 1973), 24.

${ }^{136}$... capitaneum novum galearum... HR-DAST-156, Obitelj Fanfogna-Garagnin, Spisi 1, Prijepisi, Inquisitio (16. - 17. rujna 1345.), druga i treća stranica.

${ }^{137}$ Bilježi se kao capitaneus maris u nalozima i odlukama Senata od 13. kolovoza do 20. siječnja 1347. godine. Listine 2, dok. DXCIX, str. 370, dok. DCLIII, str. 406, dok. DCLXVI, str. 416, dok. DCLXXX, str. 430. Vidi i: Morelli, Istoria, XXXIII-XXXIV; Obsidio, knj. 2, pogl. 16, str. 269-271, pogl. 18, str. 283, 286-287. Nakon 21. siječnja 1346. Andrija Maurocen bio je s Markom Giustinianijem, zapovjednikom kopnene vojske, rektor grada Zadra (do 20. siječnja 1347.). Obsidio, bilj. 179, str. 316.

${ }^{138}$ HR-DAST-156, Obitelj Fanfogna-Garagnin, Spisi 1, Prijepisi, Inquisitio (16. - 17. rujna 1345.), treća stranica. Vidi i u Prilog 1. (str. 3).

${ }^{139}$ Novčani iznos od 50.000 dukata bilježi se u dva dokumenta mletačkoga Vijeća umoljenih, 8. prosinca 1345. i 14. siječnja 1346.: ... usque ad quantitatem L mille ducatorum de denariis nostri communis... Listine 2, dok. CCCCXCV, str. 298 (1345.)... dedimus tibi et capitaneo maris et gubernatoribus, ut ipsi vel maior pars eorum possint occulte tractare de habendo civitatem predictam libere in fortia nostra, possendo promittere illis, qui sibi videbuntur, de denariis nostri communis usque ad ducatos $L$ mille... Listine 2, dok. DX, str. 309 (1346.).

${ }^{140}$ HR-DAST-156, Obitelj Fanfogna-Garagnin, Spisi 1, Prijepisi, Inquisitio (16. - 17. rujna 1345.), treća stranica. 
kom prema Zadru, posebno tijekom opsade, u kojoj je i sam aktivno sudjelovao 1345. - 1346. godine. ${ }^{141} \mathrm{U}$ prijepisu zapisnika dalje se navodi da Andrija Maurocen odobrava Uguiccioneu polazak za Zadar, čime se podrazumijeva da putuje s njim i novom mletačkom pomorskom vojskom prema zadarskom ratištu negdje krajem kolovoza 1346. godine.

Prema navedenome, Uguiccione dolazi u Veneciju u vrijeme okupljanja pete mletačke pomorske vojske za Zadar (kolovoz 1346.). ${ }^{142}$ Taj vremenski okvir, kao i odlazak mletačkoga brodovlja s područja Venecije, potvrđuju i ostali izvori. Novi zapovjednici pomorske i kopnene vojske imenuju se službeno 31. srpnja 1346. godine. Zapovjednik kopnene vojske Marko Giustiniani dobiva nalog za ukrcavanje na Maurocenove galije za Zadar 13. kolovoza, ali odgađa put zbog bolesti sina (29. kolovoza) te dolazi pod Zadar nekoliko dana nakon Maurocena, što potvrđuje i Obsidio Iadrensis. Maurocenu se daje još galija te se nalaže okupljanje svih mletačkih brodova kod Sv. Jelene, odakle se kreće prema Zadru (24. kolovoza). Nakon toga datuma Maurocenova vojska kreće prema Zadru, u koji dolazi 5. rujna 1346 . godine. ${ }^{143}$

Uguiccione stiže s njima u Zadar te odlazi u veliku mletačku bastidu, u kojoj susreće poznanike iz redova toskanskih plaćenika pristiglih istoga dana na galiji iz Venecije. Riječ je o građevini koja se u prijepisu zapisnika bilježi na sljedeći način: ... de steccato terrestri..., ... ad steccatum magnum terrestre... i ... ad steccatum... Velika bastida (stikat) mjesto je gdje se nalazi mletačka kopnena vojska pod zapovjedništvom capitanei steccati, čije se ime ne navodi. Bilježi se i kao lokacija mletačkih plaćenika i mjesto gdje boravi Uguiccione prije odlaska u grad. ${ }^{144}$ Isti stikat bilježi i Obsidio Iadrensis, gdje se kao početni datum njegove izgradnje navodi blagdan Uznesenja Križa (14. rujna) 1345. godine. ${ }^{145} \mathrm{U}$ prijepisu zapisnika

${ }^{141}$ Sa Šimunom Dandulom bilježi se kao gubernator (načelnik) u poslovima protiv Zadra. U to vrijeme bili su zajedno s glavnim vojnim zapovjednicima u Zadru. Listine 2, dok. CCCCLXXXVI (29. 11. 1345.), str. 290, dok. CCCCXCV, str. 298 (8. 12. 1345.). Tijekom 1346. sudjeluje pro factis Sclavonie u odboru zaduženom za pripreme oko nabavke brodova i vojne opreme za juriš na Zadar. Listine 2, dok. DXXII, str. 316 (6. 2. 1346.). Izabran je među petoricom providura koji su trebali otići na dogovore s vojnim zapovjednicima pod Zadrom. Imenovan je i posebnim savjetnikom za rat protiv Zadra (Savi sopra la guerra di Zara, 11. 10. 1346.). Listine 2, dok. DLXIX, str. 351-352 (21. 5. 1346.). Vidi: Andrija Maurocen (Morosini), u: Kohl, Mozzato, O'Connell, „The Rulers”, zapis br. 57520 i 71323 (izvor: Senato Secreta, 28r; Senato Secreta, 43v i 57v).

${ }^{142}$ Begonja, „Srednjovjekovno djelo”, 92, 95, 122.

${ }^{143}$ Listine 2, dok. DXCIII, str. 366-367 (31. 7. 1346.), dok. DXCIX, str. 370 (13. 8. 1346.), dok. DCVI, str. 376 (24. 8. 1346.), dok. DCX, str. 378 (29. 8. 1346.); Obsidio, knj. 2, pogl. 16, str. 270 (5. 9. 1346.). O otočiću sv. Jelene kao polazištu mletačkoga brodovlja iz Venecije vidi: Listine 2, dok. DXLVI, str. 330. ${ }^{144}$ HR-DAST-156, Obitelj Fanfogna-Garagnin, Spisi 1, Prijepisi, Inquisitio (16. - 17. rujna 1345.), prva, treća i četvrta stranica.

${ }^{145}$ Prema Obsidio Iadrensis, bastida/sticatus bila je drvena građevina izrazito velikih dimenzija podignuta izvan Zadra uz crkvu sv. Krševana ad fontem na Kolovarama. Obsidio, knj. 1, pogl. 12, str. 156-157, bilj. 71 i 73, str. 303-304. Mlečani podižu i drugu, manju bastidu iznad luke, u smjeru od 
ne postoje nikakve naznake o radovima unutar bastide, što pokazuje da je riječ o izgrađenom objektu.

Uguiccione u bastidi susreće i poznanika iz Lombardije, konjaničkoga zapovjednika Guilelma iz Piacenze (... comestabilis equester...), kod kojega je i boravio u njegovoj kući unutar bastide. ${ }^{146}$ Prema tom podatku, koji je zabilježen jedino u prijepisu zapisnika, Guilelm obavlja istu dužnost kao i prethodno navedeni konjanički zapovjednici, ${ }^{147}$ što govori da je možda u međuvremenu došlo do promjene u sastavu tih časnika. Nije isključeno ni da ih je bilo više od dvojice, ali za tu tvrdnju zasad nema potvrde u izvorima.

Prema tekstu, Guilelm je bio upoznat s dogovorom između Uguiccionea i zapovjednika Andrije Maurocena, kojega i sâm obavještava o Uguiccioneovoj spremnosti za izvršenje glavnoga zadatka. Čini se da se Guilelm na večeri družio $\mathrm{s}$ istim zapovjednikom bastide kojega se u optužnici navodi kao osobu koja je, zajedno s ostalim Mlečanima, „zavela” Uguiccionea na počinjenje kaznenih djela. ${ }^{148}$ Njegovo ime nije ostalo zabilježeno u prijepisu, ali prema ostalim izvorima znamo da je Marko Giustiniani ponovno obnašao dužnost zapovjednika kopnene vojske od kolovoza 1346. godine. ${ }^{149}$ Naime, zapovjednik kopnene vojske u op-

crkve sv. Petra prema Sv. Ivanu Evanđelistu (ultra portum). Obsidio, knj. 1, pogl. 21, str. 184; Begonja, „Srednjovjekovno djelo”, 100. Neposredno prije glavnoga juriša na Zadar Mlečani dodatno utvrđuju i pojačavaju obranu velike bastide u travnju 1346. godine. Prvoga srpnja iste godine dolazi i do velike bitke za bastidu između Mlečana, kralja Ludovika i Zadrana, pregled vidi u: Begonja, „Srednjovjekovno djelo", 102, 104-105. Detaljnije o ulozi bastida tijekom mletačko-zadarskoga rata u: Begonja, „Srednjovjekovno djelo”, 98, 101, 103, 123, 126.

${ }^{146}$ HR-DAST-156, Obitelj Fanfogna-Garagnin, Spisi 1, Prijepisi, Inquisitio (16. - 17. rujna 1345.), treća stranica.

${ }^{147}$ Vidi ovdje str. 153. Guilelma ne bilježe ni Obsidio Iadrensis ni mletački izvori, uključujući i Zadarsku kroniku, u razdoblju 1345. - 1346. godine. Vjerojatno je to bio isti onaj Guilielminus de Anguxolis de Placentia koji je zabilježen nakon zadarske opsade kao conestabel equestri 1348. - 1353. u Kopru. Katja Puppe, „Der lange Weg nach Istrien. Die venezianische Unterwerfung der Halbinsel, vornehmlich am Beispiel Kopers (1279-1349)" (doktorska disertacija, Sveučilište u Leipzigu, 2017), 192. Obitelj Anguxolis pripadala je krugu utjecajnih plemićkih obitelji u Piacenzi u 14. stoljeću, unutar koje se bilježi još nekoliko milites (Francisco, Bernard, Lancilot). Ta se obitelj bilježi kao jedna od domus militares civitatis Placentiae... Vidi: Johanne de Mussis, „Chronicon Placentinum”, u: Rerum Italicarum Scriptores ab anno aerae christianae quingentesimo ad millesimumquingentesimum, sv. 16, ur. Ludovico Antonio Muratori (Mediolano: ex typhographia societatis palatinae in regia curia, 1730), 505, 566; Cristoforo Poggiali, Memorie per la storia letteraria di Piacenza, sv. 1 (Piacenza: presso Niccolò Orcesi regio stampatore per privilegio di S.A.R., 1789) 128-129 (vidi pod bilj. A); Lodovico Antonio Muratori, "Chronicon Parmense ab anno MXXXVIII usque ad annum MCCCXXXVIII", u: Rerum italicarum scriptores: raccolta degli storici italiani dal cinquecento al millecinquecento, sv. 9, ur. Giosuè Carducci et al. (Città di Castello: S. Lapi, 1902), 95 (br. 25).

${ }^{148}$ HR-DAST-156, Obitelj Fanfogna-Garagnin, Spisi 1, Prijepisi, Inquisitio (16. - 17. rujna 1345.), prva stranica.

${ }^{149}$ Giustiniani je bio prvi zapovjednik kopnene vojske na početku opsade Zadra (kolovoz 1345. - veljača 1346.). Listine 2, dok. CCCCXXXII, str. 256; Obsidio, knj. 1, pogl. 9, str. 148., pogl. 23, str. 200. Od 13. kolovoza 1346. ponovno se spominje kao zapovjednik kopnene vojske za Zadar (capitaneus terre). 
sadi Zadra bio je ujedno i zapovjednik velike bastide, što se nije smatralo zasebnom vojnom titulom u Veneciji, stoga se nije zapisivala u mletačkim izvorima. ${ }^{150}$

U završnom izlaganju Uguiccione potvrđuje svoj odlazak sljedećega dana iz velike bastide u Zadar radi izvršenja glavnoga zadatka koji je dogovorio s pomorskim zapovjednikom. ${ }^{151}$ Sadržaj glavnoga zadatka proširuje se podacima iz uvodnoga i završnoga dijela zapisnika, koji svjedoče o planiranim metodama, subjektima i cilju. Prema tim podacima, Mlečani koriste nekoliko metoda u tajnom djelovanju protiv Zadrana: infiltraciju svojih ljudi u neprijateljske redove i podmićivanje neprijateljskih vojnika (plaćenika) u svrhu izvođenja diverzantskih akcija unutar grada. Uz stalni vojni pritisak i blokadu grada, Mlečani su koristili te (i slične) metode djelovanja tijekom cijeloga trajanja opsade, kako se opisuje u mletačkim izvorima i Obsidio Iadrensis, ${ }^{152}$ koji ih naziva mletačkim „lukavštinama i nebrojenim varkama". ${ }^{153}$

Mletački plaćenik i vođa tih planiranih akcija Uguiccione Dellosti imao je zadatak ubaciti se među svoje zemljake, toskanske vojnike (... Tuscani soldati...) u Zadru, te ih podmititi mletačkim zlatom s ciljem izvršenja dogovorenih ciljeva. Slične tajne zadatke, vezane za ponudu mita, odobravale su i nalagale službene mletačke vlasti tijekom cijele opsade, savjetujući svojim glavnim zapovjednicima neka poduzimaju takve akcije da bi se osvojio Zadar. ${ }^{154}$ Podmićivanje se Mlečanima pokazalo iznimno korisnim, posebice u osvajanju ključnih zadarskih

Listine 2, dok. DXCIX, str. 370, dok. DCX, str. 378, dok. DCXIII, str. 379. Autor Obsidio Iadrensis bilježi da Giustiniani dolazi pod Zadar nekoliko dana nakon dolaska Andrije Maurocena, poslije 5. rujna 1346. godine. Isto djelo svjedoči o njihovu zajedničkom ulasku u Zadar nakon predaje grada, kad postaju gradski rektori, što potvrđuju i ostali izvori. Obisidio, knj. 2, pogl. 16, str. 270, pogl. 18, str. 284, pogl. 19, str. 286; CD 11, dok. 256-258, str. 334-335, 337. Nakon 20. siječnja 1347. Giustiniani ostaje jedinim zapovjednikom u Zadru do dolaska savjetnikā, a nedugo zatim postaje i zadarskim knezom. Listine 2, dok. DCLXXX, str. 430, dok. DCLXXXIII, str. 431.

${ }^{150}$ Osim što je bio zapovjednik kopnene vojske, Marko Giustiniani bilježi se i kao zapovjednik bastide u Obsidio Iadrensis (capitaneus bastide - siječanj i rujan 1346.). Na sličan način zabilježen je i njegov nasljednik Petar de Canale (generalis capitaneus exercitus terrestris / capitaneus exercitus sticati). Za razliku od zadarskih, mletački izvori ne bilježe zasebno titulu zapovjednika bastide. Obsidio, knj. 1, pogl. 23, str. 198; knj. 2, pogl. 16, str. 270; Begonja, „Srednjovjekovno djelo”, 92-93. Mletački izvori zasebno bilježe samo titulu kapetana za manju zidanu utvrdu (bastita seu fortilizia de muro cum calce) koju planiraju izgraditi nakon 29. siječnja 1346. godine. Listine 2, dok. DXV, str. 311. Ista građevina i kao bastiola: Listine 2, dok. DXXIII, str. 317, dok. DXXV, str. 318.

${ }^{151}$ HR-DAST-156, Obitelj Fanfogna-Garagnin, Spisi 1, Prijepisi, Inquisitio (16. - 17. rujna 1345.), četvrta stranica.

${ }^{152}$ Begonja, „Srednjovjekovno djelo”, 96-97, 100, 105-106.

${ }^{153}$ Obsidio, knj. 1, pogl. 14, str. 158.

${ }^{154}$ Vidi ovdje str. 154. Vidi i dokument mletačkoga Vijeća umoljenih u kojem se određuje kriterij prema kojem se isplaćuju novčane nagrade vojnim jedinicama pri ulasku u Zadar (preko gradskih zidina). Visina nagrade ovisila je o vremenu ulaska pojedine čete u Zadar (prva dobiva 1.000, a ostale po 100 libri). Određena je i novčana nagrada za pojedince u Zadru koji otvore gradska vrata ili omoguće mletačkoj vojsci ulaz preko zidina (10.000 zlatnih dukata). Listine 2, dok. DLIX, str. 341. 
izvangradskih utvrda, pobjedama u važnim vojnim sukobima ili potpomaganju pobuna unutar grada. ${ }^{155}$

Najčešća ciljana skupina za izvođenje takvih akcija unutar grada bile su pojedine grupe stranih zadarskih plaćenika, ali i domaćih vojnika i stanovnika. U nekoliko navrata autor Obsidio Iadrensis opisuje takve pojedince kao izdajice ili buntovnike, ${ }^{156}$ tražeći razloge u „pohlepi za neprijateljskim novcem”. ${ }^{157}$

Prema prijepisu zapisnika, jedna od takvih skupina bili su i toskanski vojnici koji su se u vrijeme opsade nalazili unutar grada. Toskanski vojnici prisutni među zadarskim plaćenicima ${ }^{158}$ bili su strani plaćenici u službi zadarske komune, ${ }^{159}$ a njihova ukupna brojčana snaga ostaje zasad nepoznata. Prema sadržaju prijepisa, to su bili ljudi koje je Uguiccione poznavao iz svoje domovine, što upućuje na to da je imao izgrađen autoritet među njima. Uguiccioneov ugled među tim vojnicima najvjerojatnije je bio i glavni razlog zašto ga Mlečani šalju $k$ njima da zadobije njihovo povjerenje za izvršenje zadatka. Stoga se čini sasvim opravdanim tvrditi da je Uguiccione bio iskusan vojni zapovjednik koji je svoje usluge nudio i kao vojni plaćenik, što je bilo uobičajeno u tadašnjim talijanskim komunama. ${ }^{160}$

Iako se u ostalim izvorima ne bilježe izrijekom Toskanci, poznat je podatak da je zadarska komuna imala strane plaćenike u vrijeme opsade. ${ }^{161}$ Osim u prijepisu, Toskanci se izdvojeno ne bilježe ni u mletačkoj vojsci pod Zadrom iako su Mlečani imali snažnu plaćeničku vojsku sastavljenu od ljudi iz čitave Italije (veći-

${ }^{155}$ Nakon neuspješnih vojnih akcija Mlečani uspijevaju mitom dobiti dvije ključne zadarske izvangradske utvrde, sv. Kuzme i Damjana na Pašmanu i sv. Mihovila na Ugljanu. Mlečani su metodu mita koristili posebno među pripadnicima neprijateljske vojske u raznim vojnim sukobima (zadarski plaćenici, kraljevski povjerenici), a postoje i snažne indicije da su podmitili neke od sudionika pučke pobune u srpnju 1346. godine. Vidi: Obsidio, knj. 1, pogl. 22, str. 190; knj. 2, pogl. 11, str. 250, 254; Begonja, „Srednjovjekovno djelo”, 100-101, 106.

${ }^{156}$ Obsidio, knj. 1, pogl. 23, str. 196; knj. 2, pogl. 10, str. 246, pogl. 11, str. 250.

157 Obsidio, knj. 1, pogl. 22, str. 190.

${ }^{158}$ HR-DAST-156, Obitelj Fanfogna-Garagnin, Spisi 1, Prijepisi, Inquisitio (16. - 17. rujna 1345.), prva, treća i četvrta stranica.

${ }^{159}$ Obsidio Iadrensis bilježi dva zapisa o plaćenicima komune, kojih je bilo otprilike osamdeset (ne navodi njihovo podrijetlo). U prvom zapisu bilježi se osamdesetak zadarskih plaćenika u vojnoj akciji protiv Mlečana (... stipendiarii Iadrę, qui erant circa bis quadraginta...). Obsidio, knj. 2, pogl. 17, str. 273. U drugom zapisu bilježi se njih osamdeset (u početku) koji su branili zadarske vijećnike na izlasku iz općinske dvorane (Audiunt consiliarii vocum clangorem, plurimi ibidem accelerant vna cum stipendiariis comunis, qui erant primi numero octuaginta.). Obsidio, knj. 2, pogl. 18, str. 280.

${ }^{160}$ Vidi primjere djelovanja različitih plaćeničkih skupina, tzv. companies, u Italiji (14. stoljeće), uključujući i White company koju je vodio Sir John Hawkwood od 1360-ih. Michael Mallett, Mercenaries and their Masters: Warfare in Renaissance Italy (Barnsley: Pen and Sword Military, 2009), 28-41.

${ }^{161}$ Obsidio Iadrensis bilježi samo općeniti naziv za zadarske plaćenike (... stipendiarii Iadrę...). Obsidio, knj. 1, pogl. 22, str. 191; knj. 2, pogl. 17, str. 273. Mletački izvori bilježe i strane plaćenike među njima (... stipendarii forenses...). Listine 2, dok. DCXXIV, str. 387. 
nom regije Veneto i Lombardije) i mletačkih dominija. ${ }^{162}$ Prema Uguiccioneovu iskazu, osim u Zadru, toskanski vojnici nalazili su se i s mletačkom kopnenom vojskom u velikoj bastidi. Velik dio te vojske bila je ustvari plaćenička vojska, kako potvrđuju i tadašnji izvori. ${ }^{163}$ Prisutnost toskanskih plaćenika na objema stranama u tom sukobu govori u prilog tome da su Toskanci bili iskusni vojnici koji su se zapošljavali u stranim službama, što je bilo uobičajeno među plaćenicima u 13. i 14. stoljeću. ${ }^{164}$

Kako stoji u prijepisu zapisnika, glavni cilj Uguiccionea i nekolicine zadarskih plaćenika bio je osvojiti pojedine gradske kule ili utvrđene dijelove zidina (... capere de fortiliciis muri civitatis aliquam turrim bertescam... $)^{165}$ te ih predati $\mathrm{u}$ ruke mletačkim vojnicima i zapovjedniku bastide tijekom noći. Uguiccione je optužen i za planiranje „ostalih zala” (... multa alia mala...), što implicira manje akcije diverzantskoga tipa, primjerice podmetanje požara, kako se i navodi u završnom dijelu prijepisa. ${ }^{166}$

Te su optužbe u potpunoj korelaciji sa sličnim događanjima u gradu tijekom mletačkoga opsjedanja Zadra. Naime, Obsidio Iadrensis bilježi nekoliko incidenata u kojima su Mlečani, zajedno s potkupljenim zadarskim plaćenicima, nastojali osvojiti gradske kule ili dijelove obrambenih zidina. Slični događaji spominju se

\footnotetext{
${ }^{162}$ Begonja, „Srednjovjekovno djelo”, 109. U mletačkim službenim dokumentima u kojima se bilježe strani plaćenici te novačenje i opremanje galija uglavnom se spominju vojnici iz područja Veneta (Treviso, Padova), Lombardije, Cipra i dalmatinskih gradova. Listine 2, dok. CCCCXXII-CCCCXXVII, str. 252-255, dok. CCCCXXXVII, str. 260, dok. CCCCLXXII, CCCCLXXIV, str. 283-284, dok. CCCCXCIII, str. 297, dok. DXXIII, str. 316, dok. DXLIV, str. 328, dok. DLXXI, str. 352-353.

${ }^{163}$ HR-DAST-156, Obitelj Fanfogna-Garagnin, Spisi 1, Prijepisi, Inquisitio (16. - 17. rujna 1345.), treća stranica. Obsidio, knj. 1, pogl. 5, str. 128, pogl. 12, str. 156; knj. 2, pogl. 3, str. 212; Listine 2, dok. CCCCLXXIV, str. 283, dok. CCCCXCVII, str. 299-300.
}

${ }^{164}$ Pojam strani plaćenici (forenses) nije se odnosio samo na plaćenike drugih nacionalnosti u nekoj talijanskoj komuni (npr. Firenci) nego i na ljude iz drugih talijanskih gradova. Iako je većina talijanskih gradova, uključujući Firencu, imala u svojoj službi strane plaćenike, i vojnici iz tih gradova obavljali su plaćeničku službu u drugim gradovima tijekom 13. i 14. stoljeća. Usp. Mallett, Mercenaries, 13-14; Begonja, „Srednjovjekovno djelo”, 109 (bilj. 203 i 204); William Caferro, „Continuity, Long-Term Service, and Permanent Forces: A Reassessment of the Florentine Army in the Fourteenth Century", The Journal of Modern History 80 (2008), br. 2: 219-251; William Caferro, „The Florentine Army in the Age of the Companies of Adventure”, Millars: Espai i història 43, br. 2 (2017): 132, 145.

${ }^{165}$ HR-DAST-156, Obitelj Fanfogna-Garagnin, Spisi 1, Prijepisi, Inquisitio (16. - 17. rujna 1345.), prva stranica. Termin fortilicium (muri civitatis) odnosi se na manju utvrdu koja se nalazila na gradskom zidu, a turris bertesca na drvenu kulu. Usp. Marina Marasović Alujević, „Romanizmi u graditeljskoj terminologiji u Dalmaciji”, Čakavska rič: polugodišnjak za proučavanje čakavske riječi 12 (1984), br. 1-2: 67.

${ }^{166}$ HR-DAST-156, Obitelj Fanfogna-Garagnin, Spisi 1, Prijepisi, Inquisitio (16. - 17. rujna 1345.), prva stranica. ... et ipso capto debebat unum ex dictis soldatis ... scandere muros et mittere ad steccatum vel ad galeas vel ipse solus ut denunciaret capitaneo que fecerat et videre statim cum igne. HR-DAST-156, Obitelj Fanfogna-Garagnin, Spisi 1, Prijepisi, Inquisitio (16. - 17. rujna 1345.), četvrta stranica. 
nekoliko puta od siječnja do srpnja 1346., što pokazuje sličan modus operandi u planiranju, provođenju i cilju tih akcija. ${ }^{167}$

Slično je bilo i s manjim diverzantskim akcijama koje su se izvodile radi nanošenja štete neprijateljskim jedinicama ili slabljenja obrane grada. U prijepisu zapisnika ne bilježi se koje su se dodatne akcije trebale izvesti - spominje se samo riječ „,vatra” (... cum igne...), što upućuje na namjeru spaljivanja zadarskih brodova i podmetanja požara unutar grada. Slične akcije ostale su zabilježene tijekom cijeloga trajanja opsade, kako je i opisano u tadašnjim izvorima. ${ }^{168}$ Međutim, prema tim istim izvorima, ne postoje nikakvi dokazi o uspješnom izvršenju glavnoga zadatka i ostalih planiranih akcija, što upućuje na potvrdu teze o ranom uhićenju Uguiccionea. ${ }^{169}$

Kako stoji u bilješci o presudi, Uguiccione je osuđen na smrtnu kaznu dekapitacijom, o čijem izvršenju ne postoji potvrda u izvorima. ${ }^{170}$ Nigdje se ne bilježi ni je li uspio doći u kontakt s Toskancima u Zadru ni njihova sudbina nakon suđenja. Iako nije ostalo zabilježeno u izvorima, ne znači da Zadrani nisu nastojali saznati identitet tih ljudi među svojim plaćenicima. Naime, čini se da su itekako bili svjesni opasnosti od mletačkoga podmićivanja njihovih plaćenika s obzirom na to da su ih sami prisiljavali na odlazak iz grada. ${ }^{171} \mathrm{U}$ prijepisu se bilježi da je proces pokrenut protiv Uguiccionea et eius comitata, što upućuje na njegovu družinu. ${ }^{172}$ No kako ostali podaci, uključujući i Obsidio Iadrensis, ${ }^{173}$ potvrđuju da je Uguiccione bio jedini uhićenik kojemu je samostalno suđeno i na kraju presuđeno, zadarske vlasti vjerojatno nisu uhitile toskanske plaćenike. Ti podaci pokazuju da vlasti nisu znale njihov identitet, što su svakako nastojale doznati tijekom Uguiccioneova ispitivanja. Ovakvo promišljanje vodi u smjeru pretpostavke da

${ }^{167}$ Prvi slučaj odnosi se na pokušaj osvajanja gradskih kula u vrijeme glavne bitke za gradski lanac (23. siječnja 1346.). Uhvaćeni zadarski plaćenici, potkupljeni od Mlečana, javno su obješeni na vrhu pet zadarskih kula. Obsidio, knj. 1, pogl. 23, str. 192, 196, pogl. 24, str. 198. Drugi slučaj odnosi se na podmićivanje urotnika tijekom pobune pučana protiv zadarskih vlasti 23. srpnja 1346. godine. Kako navodi Obsidio Iadrensis, uhićeni urotnici/pobunjenici trebali su označiti Mlečanima veće kule na sjevernoj strani grada te otvoriti gradska vrata za slobodan ulazak mletačke vojske. Vidi: Obsidio, knj. 2, pogl. 12, str. 258. U jednom od mletačkih dokumenata jasno se nalaže glavnim zapovjednicima da treba ponuditi i novčanu nagradu (10.000 zlatnih dukata) onima koji uspiju iznutra osvojiti neka od gradskih vrata ili zidina. Listine 2, dok. DLIX, str. 341 (22. 4. 1346.). Ovaj primjer jasno dokazuje da su službene mletačke vlasti aktivno poticale politiku mita u osvajanju Zadra.

${ }^{168}$ HR-DAST-156, Obitelj Fanfogna-Garagnin, Spisi 1, Prijepisi, Inquisitio (16. - 17. rujna 1345.), četvrta stranica. Listine 2, dok. DCXXIV, str. 387; Obsidio, knj. 1, pogl. 8, str. 142, pogl. 14, str. 158, 160, pogl. 23, str. 192; Begonja, „Srednjovjekovno djelo”, 96.

${ }^{169}$ Vidi ovdje str. 142.

${ }^{170}$ Vidi ovdje str. 146.

${ }^{171}$ Obsidio, knj. 1, pogl. 14, str. 158, 160.

${ }^{172}$ HR-DAST-156, Obitelj Fanfogna-Garagnin, Spisi 1, Prijepisi, Inquisitio (16. - 17. rujna 1345.), prva stranica.

${ }^{173}$ Vidi ovdje str. 139. 
su Toskanci ostali u gradu nakon Uguiccioneova uhićenja. U prilog tome govori i nalog mletačkih vlasti izdan njihovim glavnim zapovjednicima u Zadru 26. rujna 1346., u kojem im se nalaže da pokušaju nagovoriti neke strane plaćenike u gradu da spale zadarsko brodovlje. Riječ je o stranim plaćenicima koji su bili naklonjeni mletačkoj strani te su željeli napustiti Zadar. Mlečani su im obećali novčanu nagradu za izvršenje toga djela i nesmetan izlazak iz grada. ${ }^{174}$ Iako se nigdje ne navodi o kojim je strancima riječ, nije isključeno da su to možda bili upravo toskanski plaćenici koji su se nakon Uguiccioneova smaknuća nastojali udaljiti iz grada u strahu od naknadnoga uhićenja.

\section{Zaključak}

U arhivskom fondu Obitelj Fanfogna-Garagnin Državnoga arhiva u Splitu nalazi se prijepis sudskoga zapisnika o inkvizicijskom postupku zadarskoga kaznenog suda protiv firentinskoga plemića Uguiccionea Dellosti iz rujna 1346., u vrijeme mletačko-zadarskoga rata. Prijepis, datiran u 18. stoljeće, pronađen je u zasebnom svežnjiću unutar obiteljskih spisa Fanfogna, u kojem se nalazi petnaestak prijepisa različitih, uglavnom notarskih, dokumenata iz 14 . stoljeća.

Usporedna analiza vanjskih karakteristika prijepisa (posebno rukopisa) s nekoliko prijepisa iz istoga i ostalih svežnjića pokazala je da je riječ o istom prepisivaču. Potvrdu o Domenicu Ignaziju Frauenbergeru kao prepisivaču zapisnika iz 1346. donosi sadržaj njegova potpisanog osobnog pisma pronađenog među prijepisima u istom svežnjiću (1767.).

Prema Frauenbergerovu zapisu na početku prijepisa, zapisnik je prepisan iz sudskoga registra kaznenih predmeta (Quaternus criminalium) za razdoblje srednjovjekovnoga Zadra, koji se danas smatra izgubljenim. U pismu Frauenberger potvrđuje da je spomen o zadarskom rektoru Črni Fanfogna iz 1345. pronašao u „Notariato al Criminal de Rettori di Zara”, misleći pritom na sudski registar kaznenih predmeta koji se u njegovo vrijeme nalazio u sklopu općinske kancelarije. Kako taj registar danas nije sačuvan, ovaj podatak implicira njegov kasniji nestanak iz zadarskih komunalnih arhiva. U skladu s tim, prijepis potvrđuje dosadašnje pretpostavke o postojanju ranijih registara za kaznene predmete i u Zadru,

${ }^{174}$ 1346. die 26 septembris, capta: cum per istud consilium, ut scitis, fuerit ordinatum, quod stipendiarii forenses, qui existunt in Jadra, non exeant civitatem, sed potius ob comodum agendorum nostrorum remaneant intus; consulunt, quod scribatur capitaneis maris et terre, quod caute per ilium habilem modum, qui videbitur eis, tractare possint cum dictis stipendiariis, quod ingis ponatur in navigiis inimicorum, promittendo eis de pecunia nostri communis in ea quantitate, que videbitur eis, non desistendo propterea ab eo, quod pridie scripsimus eis de facto stipendiariorum ipso-rum; et quod eis permittant exire civitatem in casu quo prefatum ingem pouerent, et dando eis pecuniam promissam. Listine 2, dok. DCXXIV, str. 387. 
slično kao u dalmatinskim i talijanskim gradovima. ${ }^{175}$ Iako je sačuvan ulomak zadarskih kaznenih zapisnika za prvu polovinu 15. stoljeća (1411. - 1413.), slični zapisnici ne postoje za 13. i 14. stoljeće. Uslijed nedostatka tih zapisnika, kao i ključnih normativnih izvora važnih za proučavanje kaznenoga sustava srednjovjekovnoga Zadra, prijepis ostaje jedino pisano svjedočanstvo o zadarskom kaznenopravnom sustavu i inkvizicijskom postupku u prvoj polovini 14. stoljeća.

Potvrdu da se radi o izvornom sudskom zapisniku donosi komparativna analiza njegova sadržaja i sličnih zapisnika u Zadru (15. stoljeće) i pojedinim talijanskim gradovima (13. - 15. stoljeće). Analizom su ustanovljene sličnosti u strukturi teksta i korištenju pravnih formulacija, što upućuje na korištenje zajedničkih pravnih formulara kao predložaka za sastavljanje takva tipa dokumenta. Osim u Zadru, slična struktura zapisnika o inkvizicijskom postupku zadržava se i u pojedinim talijanskim gradovima u 15. stoljeću (Bologna).

Sadržajnom analizom izvornoga teksta zapisanog u prijepisu uspijevaju se iščitati pravni i vojno-politički aspekt dokumenta, koji svjedoče o autentičnosti iznesenih podataka i njihovoj korelaciji sa sličnim podacima u ostalim izvorima. Pravni aspekt, određen vrstom dokumenta i zapisanom terminologijom, prikazao je strukturu inkvizicijskoga postupka, odnosno sudsku proceduru te sastav i nadležnosti kaznenoga suda, što potvrđuje postojeće spoznaje o tadašnjem zadarskom kaznenom sustavu.

Prema sadržaju zapisnika, inkvizicijski postupak trajao je najvjerojatnije dva dana počevši od pokretanja službene istrage na temelju javnoga glasa pa do trenutka izvršenja kazne. Tome u prilog govore slični primjeri u Zadru zabilježeni $\mathrm{u}$ istom razdoblju. Svi elementi procesa upućuju na uobičajenu inkvizicijsku proceduru za kategoriju teških zločina kakva se provodila u tadašnjoj europskoj kaznenoj praksi. Prema iznesenoj optužnici, riječ je o zločinu izdaje protiv zadarske komune, što se smatralo posebnom prijetnjom za javni red, mir i sigurnost grada i njegovih stanovnika. Upravo zbog takvih okolnosti postupak je proveden relativno brzo i u tajnosti. Tome u prilog svjedoči primjena sudske torture, ali i težina dosuđene kazne (dekapitacija), što je zajedničko za još nekoliko sličnih zadarskih primjera u istom razdoblju, ali i kasnije. Takav način provođenja inkvizicijskoga postupka u slučaju izdaje/urote, s primjenom strogoga penalnog sustava, govori da je zadarska komuna najoštrije kažnjavala takav čin. Ovakvo promišljanje u skladu je i s postojećim mišljenjima o povezanosti inkvizicijskoga postupka i jačanja komunalnih pravnih i političkih institucija, odnosno razvoja pravnoga poretka u dalmatinskim komunama. ${ }^{176}$

O jačanju pravnih institucija svjedoči i uloga kaznenoga suda, sastavljenog od trojice zadarskih rektora koji vode cjelokupni inkvizicijski postupak. Slični pri-

175 Vidi ovdje bilj. 32.

${ }^{176}$ Usp. Lonza, „Tužba, osveta, nagodba”, 76-77; Popić, Krojenje pravde, 65. 
mjeri zapisani u istom razdoblju bilježe da rektori izdaju uhidbene naloge te donose konačne presude u kaznenim predmetima, što je bilo u skladu s njihovim ovlastima. Naime, odlaskom mletačkoga kneza iz Zadra na početku opsade rektori postaju privremeni upravitelji grada koji preuzimaju njegove ovlasti i u području kaznene sudbenosti.

Vojno-politički aspekt izvornoga teksta određen je različitim podacima koji se bilježe u opisanim događanjima tijekom posljednje faze mletačke opsade Zadra 1346. godine. Usporednom analizom podataka o topografiji, vojnoj terminologiji (titulacije, arhitektura) i osobama zapisanih u kontekstu opisanih događanja, i iz zapisnika i iz ostalih izvora, potvrđena je autentičnost prepisanoga teksta. Na temelju tih podataka nastala je i rekonstrukcija opisanih događanja pomoću koje se došlo do saznanja o planiranim metodama, subjektima i cilju izvršenja glavnoga zadatka. Zahvaljujući tim saznanjima upotpunjena je postojeća slika o tadašnjim događanjima u Zadru, uključujući i ulogu mletačkih dužnosnika i stranih plaćenika u planiranju i izvođenju pojedinih ratnih djelovanja.

Opisani događaji odnose se na kolovoz i rujan 1346., tijekom posljednje faze mletačkih vojnih operacija u opsadi Zadra (srpanj - studeni). U više različitih izvora navode se podaci o istim osobama i događanjima koji potvrđuju da je riječ o 1346., a ne 1345., koju zapisuje prepisivač pri izradi prijepisa. Prema sadržaju zapisnika, optuženik Uguiccione Dellosti bio je firentinski plemić i plaćenik s iskustvom u vojnoj organizaciji, dobro povezan s visokim krugovima mletačke politike. Tome u prilog govori reputacija koju je imao među najvišim mletačkim dužnosnicima u Vicenzi i Veneciji. Osim reputacije, njegovo poznanstvo $s$ toskanskim plaćenicima u Zadru bilo je ključno u dobivanju naloga za izvršenje glavnoga zadatka. Nalog o zauzeću Zadra, koji se trebao realizirati uz pomoć nekolicine zadarskih plaćenika u gradu (Toskanci), Uguiccione dobiva izravno od glavnoga pomorskog zapovjednika Andrije Maurocena, uz obećanje bogate novčane nagrade. Iako nije zabilježeno u zapisniku, Maurocen je uputu za takvo postupanje najvjerojatnije dobio od mletačkoga Vijeća umoljenih, na što upućuju slični nalozi koje je Vijeće redovito slalo svojim zapovjednicima pod Zadrom tijekom cijele opsade.

Takvi nalozi potvrđuju da Mlečani aktivno primjenjuju metode tajnoga ratovanja protiv Zadrana tijekom dvogodišnje opsade, što se navodi i u ostalim izvorima, ali konkretno dokazuje zapisnikom. Uz stalni vojni pritisak koriste metode infiltracije među neprijateljske redove i podmićivanja stranih plaćenika radi osvajanja zadarskih kula i utvrđenja. Zabilježena su i manja djelovanja diverzantskoga tipa koja su trebala oslabiti obranu grada. Glavni cilj planiranih akcija bila je bezuvjetna predaja grada, kako je zabilježeno i u tadašnjim narativnim izvorima. Izvršenje tajnoga plana nije uspjelo, što pokazuje Uguiccioneovo uhićenje od zadarskih vlasti i provedeni inkvizicijski postupak. Iako mu je dosuđena smrtna kazna, ne postoji potvrda o njezinu izvršenju u ostalim izvorima, što ne mora 
nužno značiti da nije bila izvršena. Nije potvrđeno ni je li uspio doći u kontakt s plaćenicima unutar grada kako je bilo planirano. S obzirom na to da se inkvizicijski postupak vodio isključivo protiv Uguiccionea, ostaje prostora za pretpostavku o kasnijem izvlačenju toskanskih plaćenika iz Zadra uz pomoć mletačkih zapovjednika. Stalna prisutnost podmićenih plaćenika unutar zadarske obrane, i u gradu i u zadarskim izvangradskim utvrdama, svjedoči o oslanjanju mletačkih vlasti na „pomoć iznutra” radi bržega osvajanja vojnih ciljeva. Zahvaljujući prijepisu vidljiva je uloga toskanskih plaćenika kao stranih najamnika koji aktivno sudjeluju u mletačko-zadarskom ratu na objema stranama. Taj podatak ujedno potvrđuje saznanja o sudjelovanju stranih plaćenika u službi zadarske srednjovjekovne komune, o čemu zasad ne postoji veći broj provedenih istraživanja.

Iako sačuvan u obliku prijepisa, sadržaj ovoga sudskog zapisnika važan je doprinos $\mathrm{u}$ istraživanju vojne i kaznenopravne povijesti srednjovjekovnoga Zadra. U prvom redu, zapisnik donosi nova saznanja vezana za događaje posljednje faze mletačko-zadarskoga rata 1346., ukazujući pritom i na istinitost pojedinih zapisa u djelu Obsidio Iadrensis, koje je jedinstveni izvor za to razdoblje. Iako i drugi izvori bilježe podatke o ulozi mletačkih vlasti i vojnih zapovjednika u planiranju i izvršenju tajnih planova s ciljem zauzeća Zadra, prijepis zapisnika zasad je jedini izvor koji detaljno opisuje glavne aktere, planiranje i način izvršenja jednoga takva plana. Drugo, riječ je o najstarijem poznatom sadržaju zapisnika o inkvizicijskom postupku kaznenoga suda u srednjovjekovnom Zadru. Stoga je prijepis toga zapisnika i jedino pisano svjedočanstvo o srednjovjekovnoj praksi kaznenoga prava u Zadru u 14. stoljeću, a ujedno potvrđuje dosadašnje spoznaje o tim pitanjima u postojećoj zadarskoj historiografiji. 


\section{Prilog 1.}

HR-DAST-156, Obitelj Fanfogna-Garagnin, Obiteljski spisi Fanfogna 1, Prijepisi dokumenata (14. stoljeće), Inquisitio (16. - 17. rujna 1345.).

Prijepis izvornoga sudskog zapisnika o inkvizicijskom postupku zadarskoga kaznenog suda protiv Firentinca Uguiccionea Dellosti, optuženog za suradnju s Mlečanima i ratna djelovanja protiv grada Zadra. U kurzivu su intervencije prepisivača u izvorni tekst (bez numeracije listova).

\section{[str. 1] $]^{177}$}

Exemplum sumptum ex quaterno criminalium processuum tempore obsidionis ciuitatis Iadre

\section{5., die 16. mensis septembris}

Quod amputetur ei caput de gratia nobilitatis causa

1345 16/IX Cerne de Fanfogna rettore di Zara inquisisce Uguccione Dellosti per spionaggio durante l'assedio

Hec est inquisitio que fit et fieri intenditur per nobiles et sapientes viros dominum Cernem de Fafogna, dominum Thomasium Benedicti de Matafarris et dominum Damianum Philippi de Begna, rectores Iadre, ex eorum officii arbitrio et fama publica precedente adversus et contra

Uguiççionum Dellosti domini Iani de comitibus de Gala Cagalandi de Florentia et eius comitata (!) in eo, de eo et super eo quod ad eorum notitiam noviter est deductum quod dictus Uguicconus, diabolica fraude deceptus in anime sue periculum ad instantiam Venetorum et capitanei steccati hostium et inimicorum comunis Iadre, his diebus de steccato terrestri discedens de die venit sine aliqua licentia et securitate ei data per dominationem Iadre, intravit Iadram animo et proposito corrupendi et inducendi aliquos ex stipendiariis Iadre coruptela peccunie ut una secum possent capere de fortiliciis muri civitatis aliquam turrim bertescam vel locum et dare et tradere in manibus et fortia capitanei steccati et etiam Venetorum, et multa alia mala ordinare et committere debebat in grave damnum et desolationem civitatis Iadre et incolarum ipsius marium et mulierum et ut civitas Iadre potenti manu proditorie pervenire posset ad manus hostium Venetorum predictorum, et quod de predictis omnibus est publica vox et fama.

Super quibus omnibus et singulis dependentibus, coherentibus et prorsus extraneis ab eisdem... ${ }^{178}$

${ }^{177} \mathrm{~S}$ obzirom na to da u prijepisu ne postoji numeracija listova na kojima je zapisan tekst, autorica ovoga rada sama je označila brojeve stranica radi lakšega praćenja i označavanja.

${ }^{178}$ Nedovršena rečenica u izvornom tekstu (ili ju prepisivač nije prepisao). 
Die 17. mensis predicti

[str. 2]

Constitutus coram supradictis dominis rectoribus in sala palatii archiepiscopatus pro tribunali sedentibus Uguiççionus inquisitus supradictus et interrogatus ab eisdem dominis rectoribus qua de causa venit noviter Iadram et quis misit eum et etiam super contentis in dicta inquisitione, et ex eo quare nihil super predictis veritatem dicebat, positus fuit ad tormentum. Tandem quare dixit velle de certo puram dicere veritatem et causam sui adventus, fuit depositus de tormento, et sic spacio unius hore stans super se sponte dixit et confessus fuit coram dictis dominis rectoribus quod negotium scire habebat, quod videlicet post festum Sancti Be... ${ }^{179}$ de Vincentia applicuit Venetias et ex parte domini Marci Danduli, potestatis Vincentie, secum detulit licentiam recommandationis domino Marco Superantio ut ipsum recommendatum haberet, qui quidem ipsum generose recepit, et si invenerant unum florenum, dicens sibi idem dominus Marcus Superantio quod si erat ut fecit ei scriptum, faceret ita quod esset bonus homo sui, idem Uguiççionus respondit se facturum quidquid ei mandaret. Et illa hora idem dominus Marcus ivit ad dominum Andreassium Mauroceno, capitaneum novum (!) galearum et per intervallum rediens dixit sibi: ego procuravi et narravi factum tuum et quod iret cum ipso capitaneo in galea et facies quidquid tibi ordinaverit dictus capitaneus. Et sic ipse Uguiççionus, veniens super galeam domini Andrioli Zeno qui erat in comitiva galee capitanei dum perveniret in Quarnario, ivit cum dicto domino Andriolo ad cenandum in galeam dicti capitanei et post cenam ipse remansit ibidem et dictus Andreas redivit ad suam galeam. Et cepit dictus capitaneus sibi loqui quod si vellet esse valens [str. 3] homo et legalis eidem et perficere quod ei ordinaret, ipse dari faceret sibi lucrum de $\frac{50}{\mathrm{~m}}$ ducatis auri, qui Uguiççionus eidem capitaneo respondit quod erat paratus si diceret super quo, et tunc capitaneus dixit sibi: tu potes ire Iadram nam ibi multi sunt Tuscani soldati de tua patria habita domesticitate cum eis caute tractare cum eis (!) quod eius opere et industria civitas Iadre perveniret ad eius manus, et quod ipse respondit eidem se facturum. Et quod post predicta, pervenientes galee in obsidionem Iadre, ipse Uguiççionus statim descendit in terram et ivit ad steccatum magnum terrestre et ibi stetit cum certis suis notis familiaris infrascriptis soldatis in eodem steccato qui etiam imo eodemque die in galea venerant de Venetiis ad steccatum. Et quod Gulielmus de Placentia, comestabilis equester, in steccato secum locutus fuit, eo quod in Lombardia cum eo notitiam habuerat et quare ipse admiserat ad azzardum, quesivit ab ipso denarios mutuo, et illa hora dedit eidem intelligi eo quod capitaneus galearum secum tractaverat qui quidem Gulielmus confirmavit negotium et eum confortavit quod faceret. Et quod illa hora idem Gulielmus de conscientia ipsi Uguiççiono ad dictum dominum Andreasium capitaneum ivit,

${ }^{179}$ Praznina u prijepisu. Nije poznato je li bila i u izvornom tekstu. 
qui venerat in steccato, dicens eidem quod idem Uguiççionus erat paratus facere quid, idem capitaneus ei ordinaret et mandaret, qui vero Gulielmus rediens dixit sibi quod quidquid ipse capitaneus sibi promiserat attendet sibi. Et quod illo sero sequenti ipse ivit cenatus fuit ad domum dicti Gulielmi et obdormivit cum quodam socio (?) et quoddam cenaret Gulielmus stans in cenis cum capitaneo steccati misit ipsi Uguiççiono [str. 4] qualglas (!) ex parte sua. Et quod die sequenti venit Iadram animo ingrediendi civitatem et perficiendi ea que cum capitaneo tractaverat, et illa hora intravit civitatem.

Interrogatus a dictis dominis rectoribus quomodo et qua via perficere intendebatur, qui dixit quod supradicta conhabita domesticitate et notitia cum certis de soldatis numero sex et cognita finali voluntate si eos trahere posset ad suum sensum, et firmato cum eis negotio de modo et via tenenda intendebat ipse cum eis capere de nocte aliquid fortilitium civitatis quod acriter et habiliter capere posset, et ipso capto debebat unum ex dictis soldatis... ${ }^{180}$ scandere muros et mittere ad steccatum vel ad galeas vel ipse solus ut denunciaret capitaneo que fecerat et videre statim cum igne.

${ }^{180}$ Praznina u prijepisu. Nije poznato je li bila i u izvornom tekstu. 


\section{Neobjavljeni izvori}

Hrvatska - Državni arhiv u Splitu, Split - fond 156 - Obitelj Fanfogna-Garagnin (1301. - 1901.) - K. 2 (klasa) (HR-DAST-156, Obitelj Fanfogna-Garagnin).

Hrvatska - Državni arhiv u Zadru, Zadar - fond 31 - Bilježnici Zadra (HRDAZD-31-BZ), Raymundus de Modiis (1384.-1389.), b. 1 (fasc. 1), Articutius de Rivignano (1383.-1416.), b. 1 (fasc. 1).

\section{Objavljeni izvori i literatura}

„Arhivsko gradivo. Obitelj Corponese” (DAZD). Pristup ostvaren 7. 9. 2020. http://arhinet.arhiv.hr/details.aspx?ItemId=1_15458.

„Arhivsko gradivo. Obitelj Fanfogna” (DAZD). Pristup ostvaren 7. 9. 2020. http:// arhinet.arhiv.hr/details.aspx?ItemId=1_15463.

„Arhivsko gradivo. Obitelj Fanfogna-Garagnin” (HDA). Pristup ostvaren 7. 9. 2020. http://arhinet.arhiv.hr/details.aspx?ItemId=1_4630.

Barbarano de Mironi da Vicenza, Francesco. Historia ecclesiastica della città, territorio e diocese di Vicenza. Vicenza: Rosio, 1649.

Batović, Šime. „Predgovor”. U: Statuta Iadertina = Zadarski statut, uredili Josip Kolanović i Mate Križman, 7-8. Zadar: Ogranak Matice hrvatske u Zadru; Hrvatski državni arhiv, 1997.

Begonja, Sandra. „Srednjovjekovno djelo Obsidio Iadrensis / Opsada Zadra kao povijesni izvor za prikaz vojnopomorske moći Venecije u 14. stoljeću”. Povijesni prilozi 33 (2014), br. 47: 81-141.

Begonja, Sandra; Nikolić Jakus, Zrinka. „The Noble Families of Butovan and Botono in Medieval Zadar: Family Structure, Property Reconstruction, and Social Life". Povijesni prilozi 38 (2019), br. 56: 75-107.

Beuc, Ivan. „Statut zadarske komune iz 1305. godine”. Vjesnik historijskih arhiva u Rijeci i Pazinu 2 (1954): 491-781.

Blanshei, Sarah Rubin. „Criminal Justice in Medieval Perugia and Bologna”. Law and History Review 1 (1983), br. 2: 251-275.

Blanshei, Sarah Rubin. Politics and Justice in Late Medieval Bologna. Leiden; Boston: Brill, 2010.

Blanshei, Sarah Rubin; Cucini, Sara. „Criminal Justice and Conflict Resolution”. U: A Companion to Medieval and Renaissance Bologna, uredila Sarah Rubin Blanshei, 335-360. Leiden; Boston: Brill, 2018. 
Brunelli, Vitaliano. „Gli Statuta Jadertina”. Programma dell'I. R. Ginnasio superiore di Zara 49 (1906): 3-35.

Butić, Dolores. „Analiza djela Obsidio Iadrensis - od teksta do autora”. Doktorska disertacija, Sveučilište u Zagrebu, 2021.

Caferro, William. „Continuity, Long-Term Service, and Permanent Forces: A Reassessment of the Florentine Army in the Fourteenth Century". The Journal of Modern History 80 (2008), br. 2: 219-251.

Caferro, William. „The Florentine Army in the Age of the Companies of Adventure". Millars: Espai i història 43 (2017), br. 2: 129-150.

Carraway Vitiello, Joanna. Public Justice and the Criminal Trial in Late Medieval Italy: Reggio Emilia in the Visconti Age. Leiden; Boston: Brill, 2016.

Castellini, Silvestro. Storia della città di Vicenza, svezak 11. Vicenza: Tipografia Parise Edit, 1821.

Cega, Fani. „Knjižnica Garagnin Fanfogna u Muzeju grada Trogira”. Informatica Museologica 29 (1998), br. 1-2: 52-59.

D’Addario, Arnaldo. „Gangalandi, di”. Enciclopedia Dantesca. Pristup ostvaren 24. 10. 2020. www.treccani.it/enciclopedia/di-gangalandi_(Enciclopedia-Dantesca).

Dean, Trevor. „Criminal Justice in mid fifteenth-century Bologna”. U: Crime, Society and the Law in Renaissance Italy, uredili Trevor Dean i K. J. P. Lowe, 16-39. Cambridge: University Press, 1994.

Dean, Trevor. Crime and Justice in Late Medieval Italy. Cambridge: University Press, 2007.

Delfico, Melchiorre. Memorie storiche della Repubblica di San Marino. Appendice. Milano: Dalla Tipografia di Francesco Sonzogno di Gio. Battista, 1804.

Dibello, Daniele. „Marco Soranzo”. Dizionario Biografico degli Italiani, svezak 93. Pristup ostvaren 26. 10. 2020. http://www.treccani.it/enciclopedia/marco-soranzo_\%28Dizionario-Biografico\%29/.

Doenniges, Wilhelm. Acta Henrici VII. imperatoris Romanorum et monumenta quaedam alia medii aevi, Pars I. Berolini, 1839.

Dokoza, Serđo. „Archivium comunis Jadre’ u XIV. stoljeću”. Radovi Zavoda za povijesne znanosti HAZU u Zadru 48 (2006): 215-230.

Glavičić, Branimir; Vratović, Vladimir; Karbić, Damir; Kurelac, Miroslav; Ladić, Zoran, ur. Obsidio Iadrensis = Opsada Zadra. Monumenta spectantia historiam Slavorum Meridionalium 54, Scriptores VI. Zagreb: HAZU, 2007.

Grbavac, Branka. „Notarijat na istočnojadranskoj obali od druge polovine 12. do kraja 14. stoljeća”. Doktorska disertacija, Sveučilište u Zagrebu, 2010. 
Grbavac, Branka. „Svjedočanstvo o stvarnosti ili fikcija - zadarski notari između formulara i prakse". Acta Histriae 19 (2011), br. 3: 393-406.

Ikins Stern, Laura. „Public Fame in the Fifteenth Century”. The American Journal of Legal History 44 (2000), br. 2: 198-222.

Ius civile vincentinum. Venezia: Francesco Bindoni i Maffeo Pasini, 1539.

Kantorowicz, Hermann U., ur. Albertus Gandinus und das Strafrecht der Scholastik. Berlin: J. Guttentag Verlagsbuchhandlung, 1907.

Karbić, Damir; Ladić, Zoran. „Uvod - Kronologija događaja”. U: Obsidio Iadrensis = Opsada Zadra. Monumenta spectantia historiam Slavorum Meridionalium 54, Scriptores VI, uredili Branimir Glavičić, Vladimir Vratović, Damir Karbić, Miroslav Kurelac i Zoran Ladić, 21-35. Zagreb: HAZU, 2007.

Klaić, Nada; Petricioli, Ivo. Zadar u srednjem vijeku do 1409. Prošlost Zadra II. Zadar: FFZd, 1976.

Klaić, Vjekoslav. Povjest Hrvata. Od najstarijih vremena do svršetka XIX. stoljeća, svezak 2, dio prvi: Treće doba: vladanje kraljeva iz raznih porodica (1301-1526). Zagreb: Tisak i naklada knjižare Lav. Hartmana (Kugli i Deutsch), 1900.

Kohl, Benjamin G.; Mozzato, Andrea; O’Connell, Monique, ur. „The Rulers of Venice, 1332-1524. Interpretations, Methods, Database" (online baza podataka). Pristup ostvaren 24. 10. 2020. http://rulersofvenice.org/main.

Kolanović, Josip; Križman, Mate, ur. Statuta Iadertina = Zadarski statut. Zadar: Ogranak Matice hrvatske u Zadru; Hrvatski državni arhiv, 1997.

Kolić, Dubravka. HR-DAZD-349 Corponese (1413. - 1844.). Analitički inventar. Zadar: Državni arhiv u Zadru, 2007, 1-27. Pristup ostvaren 7. 9. 2020. https:// www.dazd.hr/attachment/preview/5c657cc6b6fb9/dazd-349-corponese.pdf.

Kolić, Dubravka; Leljak, Robert. HR-DAZD-354 Obitelj Fanfogna (1355. - 1673.). Sumarni inventar. Zadar: Državni arhiv u Zadru, 2009, 1-13. Pristup ostvaren 7. 9. 2020. https://www.dazd.hr/attachment/preview/5c657cc7df007/dazd-354-Fanfogna.pdf.

Kurelac, Miroslav; Karbić, Damir. „Uvod - Ljetopis 'Obsidionis Iadrensis Libri Duo', njegovo historiografsko i povijesno značenje”. U: Obsidio Iadrensis = Opsada Zadra. Monumenta spectantia historiam Slavorum Meridionalium 54, Scriptores VI, uredili Branimir Glavičić, Vladimir Vratović, Damir Karbić, Miroslav Kurelac i Zoran Ladić, 3-20. Zagreb: HAZU, 2007.

Lane, Frederic C.. Venice. A Maritime Republic. Baltimore: The Johns Hopkins University Press, 1973.

Leljak, Robert, ur. Inventari fonda Veličajne općine zadarske Državnog arhiva u Zadru godine 1325. - 1385., svezak 1. Zadar: Državni arhiv u Zadru, 2006. 
Lett, Didier. „Gender, childhood and sexual violence in the judicial archives of fifteenth-century Bologna”. Clio. Women, Gender, History 42 (2015): 200-212.

Lonza, Nella. „'Pred gosparom knezom i njegovim sucima....': Dubrovački kazneni postupci s početka XIV. stoljeća". Anali Zavoda za povijesne znanosti HAZU u Dubrovniku 30 (1992): 25-54.

Lonza, Nella. „Tužba, osveta, nagodba: modeli reagiranja na zločin u srednjovjekovnom Dubrovniku". Anali Zavoda za povijesne znanosti HAZU u Dubrovniku 40 (2002): 57-104.

Lonza, Nella. „Srednjovjekovni zapisnici dubrovačkog kaznenog suda: izvorne cjeline i arhivsko stanje”. Anali Zavoda za povijesne znanosti HAZU u Dubrovniku 41 (2003): 45-74.

Lučić, Nikša. „Frauenberger”. Hrvatski biografski leksikon, mrežno izdanje. Leksikografski zavod „Miroslav Krleža”. Pristup ostvaren 8. 10. 2020. https://hbl. lzmk.hr/clanak.aspx?id=6379.

Ljubić, Šime, ur. Listine o odnošajih izmedju južnoga Slavenstva i Mletačke Republike, knjiga II: Od godine 1336. do 1347. Monumenta spectantia historiam Slavorum Meridionalium, svezak 2. Zagreb: JAZU, 1870.

Ljubić, Šime, ur. Listine o odnošajih izmedju južnoga Slavenstva i Mletačke Republike, knjiga III: Od godine 1347. do 1358. Monumenta spectantia historiam Slavorum Meridionalium, svezak 3. Zagreb: JAZU, 1872.

Maffei, Elena. Dal reato alla sentenza. Il processo criminale in età comunale. Rim: Storia e Letteratura, 2005.

Mallett, Michael. Mercenaries and their Masters: Warfare in Renaissance Italy. Barnsley: Pen and Sword Military, 2009.

Manarini, Edoardo. I due volti del potere: una parentela atipica di ufficiali e signori nel regno italico. Milano: Ledizioni, 2016.

Marasović Alujević, Marina. „Romanizmi u graditeljskoj terminologiji u Dalmaciji”. Čakavska rič: polugodišnjak za proučavanje čakavske riječi 12 (1984), br. 1-2: 55-103.

Margetić, Lujo. „O nekim osnovnim značajkama pokretanja kaznenog postupka u srednjovjekovnim dalmatinskim gradskim općinama". Hrvatski ljetopis za kazneno pravo i praksu 5 (1998), br. 1: 393-449.

Meyer Setton, Kenneth. The Papacy and the Levant, 1204-1571, svezak 1. Philadelphia: American Philosophical Society, 1976.

Morelli, Jacopo, ur. Istoria dell'assedio e della ricupera di Zara fatta da Veneziani nell'anno MCCCXLVI scritta da autore contemporaneo. Monumenti veneziani di varia litteratura. Venezia, 1796. 
Morović, Hrvoje. „O trogirskoj knjižnici Garanjin-Fanfonja”. Vjesnik bibliotekara Hrvatske 10 (1964), br. 3-4: 95-106.

Muratori, Lodovico Antonio. „Chronicon Parmense ab anno MXXXVIII usque ad annum MCCCXXXVIII". U: Rerum italicarum scriptores: raccolta degli storici italiani dal cinquecento al millecinquecento, svezak 9, uredili Giosuè Carducci, Vittorio Fiorini i Giuliano Bonazzi, 1-259. Città di Castello: S. Lapi, 1902.

Mussis, Johanne de. „Chronicon Placentinum”. U: Rerum Italicarum Scriptores $a b$ anno aerae christianae quingentesimo ad millesimumquingentesimum, svezak 16, uredio Ludovico Antonio Muratori, 447-634. Mediolano: ex typhographia societatis palatinae in regia curia, 1730.

Novosel, Filip. „Društvene prilike i svakodnevlje Zadra u pozadini vojnih zbivanja za vrijeme Kandijskoga rata”. Doktorska disertacija, Sveučilište u Zagrebu, 2018.

Ortalli, Gherardo; Pittarello, Ornella, ur. Cronica Jadretina. Venezia - Zara, 1345-1346. Venezia: Istituto Veneto di Scienze, Lettere ed Arti, 2014.

Paganelli, Jacopo. „Et fuit de Scolaribus de Florentia’. Un profilo di Alberto vescovo di Volterra (1261-69)”. Rassegna volterrana XCIII (2016): 109-156.

Pagliarino, Battista. Croniche di Vicenza, knjiga 1. Vicenza: Appresso Giacomo Amadio, stampator della citta, 1663.

Passagerii, Rolandinus. Svmma artis notariae Do. Rolandini Rodvlphini Bononiensis [... ]. Lvgdvni: Apud haeredes Iacobi Iuntae, 1559.

Pennington, Kenneth. „Introduction to the Courts”. U: The History of Courts and Procedure in Medieval Canon Law, uredili Wilfried Hartmann i Kenneth Pennington, 3-29. Washington, D. C.: The Catholic University of America Press, 2016.

Plakotos, Giorgos. „Rumours, Gossip and Crypto-Jewish Identity in the Sixteenth-Century Venetian Inquisition". Annali della Scuola Normale Superiore di Pisa. Classe di Lettere e Filosofia 1, Inquisizioni (2009), br. 2: 425-443.

Poggiali, Cristoforo. Memorie per la storia letteraria di Piacenza, svezak 1. Piacenza: presso Niccolò Orcesi regio stampatore per privilegio di S.A.R., 1789.

Popić, Tomislav. „Izvorne cjeline srednjovjekovnih zadarskih sudskih zapisnika u arhivskom fondu Curia maior ciuilium". Historijski zbornik 64 (2011), br. 2: 321-376.

Popić, Tomislav. „Zadarska Curia consulum et maris i njezini zapisnici iz druge polovice 14. i prve polovice 15. stoljeća”. Povijesni prilozi 30 (2011), br. 41: 143-171.

Popić, Tomislav. „Zadarski sud Curia maior ciuilium i njegovo djelovanje”. Doktorska disertacija, Sveučilište u Zagrebu, 2011. 
Popić, Tomislav. „Srednjovjekovni zadarski kapitulari”. Povijesni prilozi 31 (2012), br. 42: 43-80.

Popić, Tomislav. Krojenje pravde. Zadarsko sudstvo u srednjem vijeku (1358. 1458.). Zagreb: Plejada, 2014.

Popić, Tomislav. „The Fourth Lateran Council and the Functioning of Courts in Thirteenth Century Eastern Adriatic". U: The Fourth Lateran Council: An Event That Transformed Europe, uredili Ivan Majnarić, Daniel Patafta i Marko Jerković, 35-59. Zagreb: Catholic University of Croatia; University of Zagreb - Catholic Faculty of Theology; Croatian Franciscan Province of Saints Cyril and Methodius; Kršćanska sadašnjost, 2019.

Puppe, Katja. „Der lange Weg nach Istrien. Die venezianische Unterwerfung der Halbinsel, vornehmlich am Beispiel Kopers (1279-1349)". Doktorska disertacija, Sveučilište u Leipzigu, 2017.

Rački, Franjo. „Iztraživanja u pismarah i knjižnicah dalmatinskih”. Rad JAZU 26 (1874): 153-188.

Ravančić, Gordan. „Curia maior ciuilium - najstariji sačuvani registar građanskih parnica srednjovjekovnog Zadra (1351. - 1353.)”. Radovi Zavoda za povijesne znanosti HAZU u Zadru 43 (2001): 85-160.

Repetti, Emanuele, ur. Dizionario geografico fisico storico della Toscana, svezak 2. Firenze: coi Tipi di A. Tofani, 1835.

Smičiklas, Tadija, ur. Codex diplomaticus regni Croatiae, Dalmatiae et Slavoniae = Diplomatički zbornik Kraljevine Hrvatske, Dalmacije i Slavonije, svezak 11. Zagreb: JAZU, 1913.

Stipišić, Jakov. „Regesta pergamena iz zbirke obitelji Fanfogna Garagnin u Muzeju grada Trogira (Dio prvi - Pergamene XIII., XIV. i XV. stoljeća)". Zbornik Odsjeka za povijesne znanosti Zavoda za povijesne i društvene znanosti HAZU 20 (2002): 289-321.

„Sumptum” (par les Bénédictins de St. Maur, 1733-1736). U: Carolus du Fresne du Cange et al., Glossarium mediae et infimae latinitatis. Niort: L. Favre, 1883-1887, t. 7, col. 656a. Pristup ostvaren 7. 9. 2020. http://ducange.enc.sorbonne.fr/SUMPTUM.

Šišić, Ferdo. „Ljetopis Pavla Pavlovića patricija zadarskoga”. Vjestnik Kr. hrvatsko-slavonsko-dalmatinskog zemaljskog arkiva 6 (1904): 1-59.

Targioni Tozzetti, Giovanni. Relazioni D’Alcuni Viaggi Fatti In Diverse Parti Della Toscana Per Osservare Le Produzioni Naturali, E Gli Antichi Monumenti Di Essa, svezak 12. Firenze: Cambiagi, 1779.

Thacker, Alan. „Popes, Patriarchs and Archbishops and the Origins of the Cult of the Martyrs in Northern Italy". U: Saints and Sanctity. Studies in Church History, 
svezak 47, uredili Peter Clarke i Tony Claydon, 51-79. Woodbridge: Boydell \& Brewer, 2011.

Tiepolo, Maria Francesca; Girgensohn, Dieter; Ortalli, Gherardo, ur. Venezia Senato. Deliberazioni miste. Registro XXII (1344-1345), svezak 9. Venezia: Istituto Veneto di Scienze, Lettere ed Arti, 2007.

Tomašević, Goran; Krstulović Dragičević, Antonija; Pleić, Marija. „Pravni položaj okrivljenika u kaznenom postupku dalmatinskih statuta". Hrvatski ljetopis za kazneno pravo i praksu 21 (2014), br. 1: 77-108.

Tura, Diana. „Archival Sources: Governmental, Judicial, Religious, Familial”. U: A Companion to Medieval and Renaissance Bologna, uredila Sarah Rubin Blanshei, 26-41. Leiden; Boston: Brill, 2018.

Valenti, Filippo. Scritti e lezioni di archivistica, diplomatica e storia istituzionale. Pubblicazioni degli Archivi di Stato Saggi 57. Ministero per i beni e le attività culturali, Ufficio centrale per i beni archivistici, 2000.

Vallerani, Massimo. „Il Liber terminationum del comune di Perugia”. Mélanges de l'Ecole française de Rome. Moyen-Age, Temps modernes 99 (1987), br. 2: 649699.

Vallerani, Massimo. Medieval Public Justice. Washington, D. C.: The Catholic University of America Press, 2012.

Vallerani, Massimo. „Criminal Court Procedure in Late Medieval Bologna: Cultural and Social Contexts". U: Violence and Justice in Bologna 1250-1700, uredila Sarah Rubin Blanshei, 27-53. Lanham; Boulder; New York; London: Lexington Books, 2018.

Vežić, Pavuša. „Nadbiskupska palača u Zadru”. Peristil 22 (1979): 17-35.

„Vodič Državnog arhiva u Zadru. Obitelj Fanfogna” (DAZD). Pristup ostvaren 7. 9. 2020. https://vodic.dazd.hr/dazd-0354/.

„Vodič Državnog arhiva u Zadru. Obitelj Katić” (DAZD). Pristup ostvaren 7. 9. 2020. https://vodic.dazd.hr/dazd-0356/.

„Vodič Državnog arhiva u Zadru. Općina Zadar” (DAZD). Pristup ostvaren 7. 9. 2020. http://dazd.hr/vodic/dazd-0019/.

Zorzi, Andrea. „The judicial system in Florence in the fourteenth and fifteenth centuries". U: Crime, Society and the Law in Renaissance Italy, uredili Trevor Dean i K. J. P. Lowe, 40-58. Cambridge: University Press, 1994. 
Sandra Begonja ${ }^{*}$

\section{Nervus belli, pecunia infinita - The Venetian Plan for Occupying Zadar in the Trial Record of an Inquisitorial Procedure from 1346}

\section{Summary}

An unknown trial record of an inquisitorial procedure from 14th-century Zadar has been found among the documents of the Zaratin noble family of Fanfogna, in the "Fanfogna-Garagnin" family fond in the State Archives in Split. The document is preserved in an 18th-century copy. The inquisitorial procedure was initiated and conducted by the Zaratin criminal court against the Florentine nobleman Uguiccione Dellosti on September 16-17, 1346. Uguiccione was accused of secret dealings with Venetian commanders in order to conquer the city from within during the last phase of the Venetian siege. Considering that the trial record was copied from the lost criminal court register for medieval Zadar (Quaternus criminalium), this document is also the only written testimony about the criminal justice system and court practice in Zadar during the first half of the 14th century. Also, the copy confirms that the register was still in Zadar during the 18th century. This article analyses the main features of the copy as well as the content of the original legal text (trial record) in order to determine the authenticity of the data and their correlation with similar data in other sources from the same period. The copy was made by Domenico Ignazio Frauenberger, the Zaratin archivist of the Fanfogna library, at some point in the second half of the 1760s. This conclusion has been reached on the basis of a comparative analysis of the main features of this copy and some other copies in the same archival fond (mostly handwritten). However, the authorship and date of the copy have been confirmed by a signed personal letter of Frauenberger's, found in the same bundle. A structural analysis of the text has revealed Frauenberger's interventions during the copying process as well as some late interventions by an unknown person. Also, the original text shows similarities with other inquisitorial records of some Italian communes (13th-15th centuries), mostly in structure and the legal formula, which indicates a possible use of common legal templates. The original text from 1346 also shows similarities with another Zaratin trial record from 1412, which indicates a similar way of keeping inquisitorial records in the second half of the 14th century.

A content analysis of the original text has confirmed the legal and military political aspects that determine the value of this document. The analysis of the legal aspect has established the type of legal document (trial record), the structure of the inquisitorial procedure, and the composition and jurisdiction of the criminal court. These data are also an important indicator of the penal system in medieval Zadar, about which we have almost no knowledge. The inquisitorial procedure was short and kept in secret. The method of torture was applied in order to extract a true statement. Although the final

\footnotetext{
Sandra Begonja, Croatian Institute of History, Opatička 10, 10000 Zagreb, Croatia, E-mail: phelgor@yahoo.co.uk
} 
verdict of the court was death sentence by decapitation, it is not known whether it was executed. Comparative Zaratin and Italian sources have shown similarities in the implementation of the same procedure in case of betrayal as one of the most serious public crime against the commune. The criminal court (three Zaratin rectors) conducted the inquisitorial procedure from the moment of arrest to the passing of the verdict. After the departure of the Venetian count from the city at the beginning of the siege, the rectors took over his jurisdiction in resolving criminal cases. The military political aspect of the document contains various data on the recorded events during the last phase of the Venetian siege of Zadar (August / September 1346). The authenticity of the original text has been confirmed by a comparative analysis of data on topography, military terminology (titles, architecture), and persons in the recorded events (including other sources). The exact date of the original text (1346) and the time frame of the events narrated in the defendant's testimony have been established, as well as the relationship between Uguiccione and the Venetian employers, confirming Uguiccione as a military commander who was employed as a foreign mercenary in the recorded events. Uguiccione was instructed to carry out the main task given by the naval commander Andrea Maurocen. Besides Marco Giustiniani, commander of the Venetian land army, Maurocen was one of the main coordinators of Venetian military operations in the siege of Zadar. He was most likely instructed to act upon demand by the official Venetian authorities, who sent similar orders to their commanders in Zadar on several occasions during the siege. The reconstruction of the recorded events has also revealed the planned methods, subjects, and the main goal of the secret plan. This knowledge complements the existing picture of the siege of Zadar, including the role of Venetian commanders and foreign mercenaries in the planning and execution of certain war activities. Uguiccione was instructed to infiltrate and bribe some of his fellow soldiers among the Zaratin mercenaries. Their main goal was to conquer some of the city towers and fortifications, and hand them over to the Venetians. This method was one of the many military tactics that the Venetians applied during the siege of Zadar. The target group among the Zaratin mercenaries were the Tuscan soldiers, who were also part of the Venetian army at that time, which indicates that they fought on both sides in this war. Since the original text does not record their arrest, the Tuscans most likely remained in the city after Uguiccione's arrest. This is also indicated by some official Venetian sources from that time. Besides the Venetian-Tuscan connection in this war, these data also confirm the presence of foreign mercenaries in the service of the medieval commune of Zadar, about which we have almost no knowledge.

Keywords: Zadar, 14th century, siege of Zadar, Venetians, Tuscan mercenaries, criminal court records, inquisitorial procedure 